Florida International University

FIU Digital Commons

$11-12-2019$

\title{
Coupling Telemetry and Stable Isotope Techniques to Unravel Movement: Snook Habitat Use Across Variable Nutrient Environments
}

Cody W. Eggenberger

Florida International University, coeggenb@fiu.edu

Follow this and additional works at: https://digitalcommons.fiu.edu/etd

Part of the Environmental Studies Commons

\section{Recommended Citation}

Eggenberger, Cody W., "Coupling Telemetry and Stable Isotope Techniques to Unravel Movement: Snook Habitat Use Across Variable Nutrient Environments" (2019). FIU Electronic Theses and Dissertations. 4305.

https://digitalcommons.fiu.edu/etd/4305

This work is brought to you for free and open access by the University Graduate School at FIU Digital Commons. It has been accepted for inclusion in FIU Electronic Theses and Dissertations by an authorized administrator of FIU Digital Commons. For more information, please contact dcc@fiu.edu. 


\title{
FLORIDA INTERNATIONAL UNIVERSITY
}

Miami, Florida

\section{COUPLING TELEMETRY AND STABLE ISOTOPE TECHNIQUES TO UNRAVEL MOVEMENT: SNOOK HABITAT USE ACROSS VARIABLE NUTRIENT ENVIRONMENTS}

\author{
A thesis submitted in partial fulfillment of \\ the requirements for the degree of \\ MASTER OF SCIENCE \\ in \\ ENVIRONMENTAL STUDIES \\ by
}

Cody William Eggenberger 
To: Dean Michael R. Heithaus

College of Arts, Sciences, and Education

This thesis, written by Cody William Eggenberger, and entitled Coupling Telemetry and Stable Isotope Techniques to Unravel Movement: Snook Habitat Use Across Variable Nutrient Environments, having been approved in respect to style and intellectual content, is referred to you for judgment.

We have read this thesis and recommend that it be approved.

Elizabeth Anderson

Yannis Papastamatiou

Leonard Scinto

Jennifer Rehage, Major Professor

Date of Defense: November 12, 2019

The thesis of Cody William Eggenberger is approved.

Dean Michael R. Heithaus

College of Arts, Science and Education

Andrés G. Gil

Vice President for Research and Economic Development and Dean of the University Graduate School

Florida International University, 2019 
(C) Copyright 2019 by Cody William Eggenberger

All rights reserved. 


\section{DEDICATION}

I dedicate this thesis to my parents, Carolyn and Eric, and my brother, Tristan. Without their love, support, and encouragement, none of this would have been possible. 


\section{ACKNOWLEDGMENTS}

I would like to express my special appreciation and thanks to my advisor, Professor Jennifer Rehage. You have been a tremendous mentor to me. I would like to thank you for patient guidance, encouragement and advice that has allowed me to grow as a research scientist. Your advice with both research as well as life have been invaluable, and I look forward to continuing into my Ph.D. under your advisement.

I would like to express my special appreciation and thanks to Professors Elizabeth Anderson, Yannis Papastamatiou, and Leonard Scinto for serving as my committee members and their advice throughout my Master's. I would also like to thank Professor Jimmy Nelson, Dr. Tom Frankovich, soon-to-be Dr. Ryan James, and the contributing members of the Rehage lab for their dedicated help with this project. In particular, I would like to especially thank Dr. Rolando Santos for the tremendous amount of help and guidance he has provided throughout my time here at FIU. Your support and advice have been extremely helpful and have pushed me to grow as a researcher.

Finally, a very special thanks to the South Florida Water Management District, the Ocean Tracking Network, the Everglades Foundation, the Florida Coastal Everglades Long Term Ecological Research (FCE LTER) program, and the FIU CREST CACHE for providing the funding for this work. 


\section{ABSTRACT OF THE THESIS \\ COUPLING TELEMETRY AND STABLE ISOTOPE TECHNIQUES TO UNRAVEL MOVEMENT: SNOOK HABITAT USE ACROSS VARIABLE NUTRIENT ENVIRONMENTS \\ by}

Cody William Eggenberger

Florida International University, 2019

Miami, Florida

Professor Jennifer Rehage, Major Professor

Habitat selection by organisms can be driven by a number of factors, including the availability of resources. In particular, nutrient enrichment can alter the quality of landscapes, and thus the availability of resources, with implications for consumer movement and habitat use. In coastal ecosystems, eutrophication can affect the production and distribution of resources, and thus the behaviors and space use of consumers. In this study, I coupled acoustic telemetry methods and stable isotope analyses (SIA) to examine the effects of nutrient enrichment on the movement, habitat use, and resource use of Common Snook (Centropomus undecimalis), a valuable recreational fishery, across two neighboring estuarine lake systems of varying trophic state (eutrophic vs. mesotrophic), located in Florida Bay (Florida, USA). The present thesis work highlights the value of cross-site comparisons that pair movement and trophic measurements to improve our understanding of how animals select habitats under varying environmental conditions and production regimes. 


\section{TABLE OF CONTENTS}

CHAPTER

PAGE

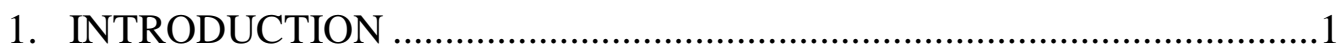

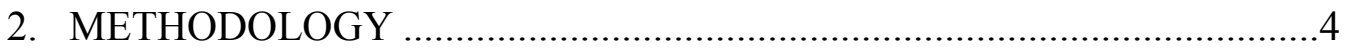

2.1 Study System ..................................................................... 4

2.2 Snook Movement Tracking....................................................6

2.3 Snook Tagging and Sample Collection.....................................

2.4 Laboratory Isotope Analysis ................................................. 9

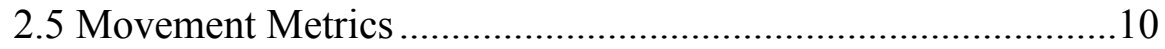

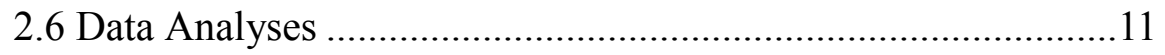

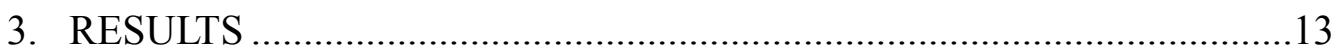

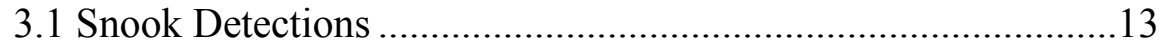

3.2 Variation in Movement Metrics............................................. 14

3.3 Variation in Basal Resource and Trophic Level ........................16

3.4 Relating Movement to Resource Use ....................................17

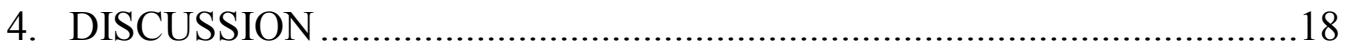

4.1 Variation in Snook Movement and Residency ........................20

4.2 Trophic Variation Across Systems ........................................24

4.3 Coupling of Movement and Trophic Patterns..........................25

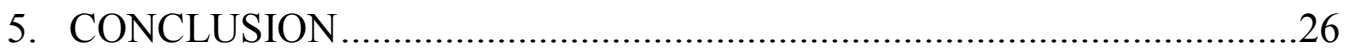

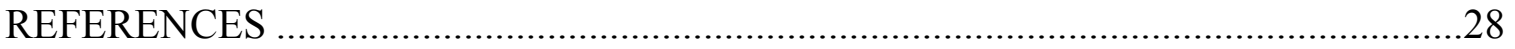

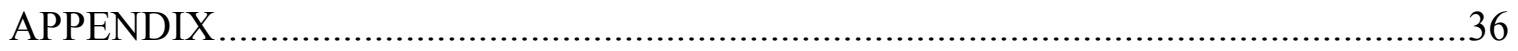




\section{LIST OF TABLES}

TABLE

PAGE

1. Results of model selection including the generalized linear mixed models (GLMM) considered to assess variance in the two movement metrics

2. MixSIAR model results showing breakdown of the source contribution to Snook

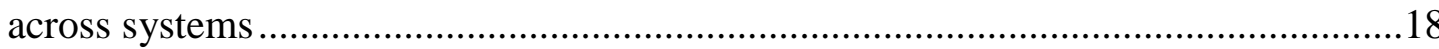

3. Summary of results for the analysis of deviance for the generalized linear models (GLM) used to assess variation in a) inter-zone movement events and b) movement event duration as function of trophic level (TL) and zones ......................................20 


\section{LIST OF FIGURES}

FIGURE

PAGE

1. The Coastal Everglades Lakes Acoustic Array $\left(\right.$ CELA $\left.^{2}\right)$.......................................

2. Habitat use metrics for Snook across zones and the two focal lake systems, eutrophic and mesotrophic and for zones within each system ............................................... 16

3. Stable isotope biplots of basal resources for each system ..................................17

4. Boxplots of the source contributions to Snook and trophic level determined by

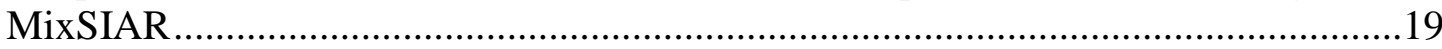

5. Fit of generalized linear models (GLMs) to assess the relationships between Snook

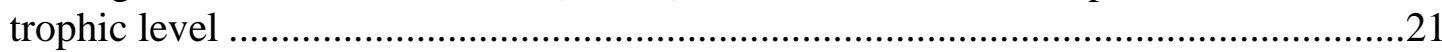




\section{ABBREVIATIONS AND ACRONYMS}

\begin{tabular}{|c|c|}
\hline AIC & Akaike Information Criterion \\
\hline BMA & Benthic Microalgae \\
\hline $\mathrm{CELA}^{2}$ & Coastal Everglades Lakes Acoustic Array \\
\hline DO & Dissolved Oxygen \\
\hline ENP & Everglades National Park \\
\hline FCE & Florida Coastal Everglades \\
\hline FL & Florida \\
\hline GLMMs & Generalized Linear Mixed Models \\
\hline LTER & Long Term Ecological Research \\
\hline $\mathrm{ME}$ & Movement Event \\
\hline MED & Movement Event Duration \\
\hline POM & Particulate Organic Matter \\
\hline SAV & Submerged Aquatic Vegetation \\
\hline SIA & Stable Isotope Analyses \\
\hline TL & Trophic Level \\
\hline USA & United States of America \\
\hline
\end{tabular}




\section{INTRODUCTION}

Multiple mechanisms can affect the habitat selection of organisms over space and time, including physiological limitations, resource distribution, predation risk, and social interactions (Gallagher et al., 2017; Moore \& Aborn, 2000; Block \& Brennan, 1993). Among these, the availability of resources can significantly influence the behavioral strategies of mobile consumers (Stephens \& Krebs, 1986; Werner \& Hall, 1974; Fretwell \& Lucas, 1969). Landscape theory predicts that small home ranges are favored in habitats where resources are homogenous, and temporally stable (Mueller \& Fagan, 2008). Nutrient enrichment can alter the quality of landscapes, and thus the stability of resources in space and time, resulting in shifts in mobile consumer behavior as species may increase their movement rates and home range to acquire sufficient resources (Oberdorff et al., 2001).

Coastal eutrophication can have both pronounced and subtle effects on the production and distribution of resources that can subsequently alter the behaviors and distributions of prey (Craig \& Crowder, 2005), and thus the behaviors and distribution of consumers. These effects can result from the direct effects of eutrophication, such as changing production regimes, or from indirect effects such as altered habitat availability and/or structure (Nelson et al., 2018; Moss et al., 2011; Brönmark et al., 1992). Although it is likely that such changes in resources will alter consumer movement patterns, very little research has been done to explicitly determine the cascading effects on consumer movement and space use patterns (Breitburg et al., 2009).

New tagging technologies, including passive acoustic telemetry, are allowing for an unprecedented understanding of the movement and space use of animals (Boucek and 
Morley, this issue; Hussey et al., 2015; Kays et al., 2015). These technologies provide opportunities to ask "big questions" concerning the underlying mechanisms driving movement (Nathan et al., 2008; Donaldson et al., 2014), as well as the effectiveness of restoration efforts (Hall et al., this issue). In particular, the pairing of these technologies with tools such as stable isotope analysis (SIA) can be a powerful approach to improving our understanding of the linkages between the foraging and movement ecology of animals, yet studies integrating these approaches remain limited (Harrison et al., 2017). A handful of previous studies have coupled tracking and SIA to examine topics such as movement patterns as they relate to foraging (Matich and Heithaus, 2014; Carlisle et al., 2012), inter-individual variation (Harrison et al., 2017), and food web linkages (Rosenblatt and Heithaus, 2011).

In the current cross-site study, we used a coupled trophic-movement ecology approach to examine how enrichment may be altering fish space use and habitat selection mechanisms. We compared movements, habitat use patterns, and trophic characteristics for a key recreational fish species, Common Snook (Centropomus undecimalis), across two neighboring lake systems with varying trophic states (eutrophic vs. mesotrophic) in Florida Bay, Everglades National Park (ENP, Florida, USA). Common Snook are a highly targeted recreational sportfish in Florida (Muller et al. 2015), and the intent of this cross-site approach is to provide valuable information on the effects of coastal nutrient enrichment that may be beneficial to the sustainability of the fishery. The coastal Everglades have been altered by reductions in freshwater inflows and associated habitat changes (Kelble et al., 2007; Lee et al., 2016; Fourqurean \& Robblee, 1999; Boyer et al., 1997), but little is known about how these post-drainage conditions affect the 
economically-valuable recreational fisheries the ecosystem supports. Recently, the Everglades recreational fishery was valued at $\$ 1.2$ billion annually, but current estimates suggest that about $\$ 69$ million in recreational services are lost every year due to reduced freshwater inflows (Brown et al., 2018). Understanding how alterations to the Everglades ecosystem, particularly those related to enrichment, are affecting recreational sportfish distributions and trophic dynamics is critical to sustaining the health of recreational fisheries. A cross-site approach, where we are able to compare neighboring, yet distinct coastal systems provides an ideal setting for improving our understanding of how an organism's trophic and movement ecology are linked.

More specifically, the goal of the present study was to examine the relationship between movement and resource use in Snook across two subestuarine systems of varying trophic state (eutrophic vs. mesotrophic). Specifically, we compared variation in Common Snook (1) movement patterns and habitat use, (2) basal resources use and trophic levels, and (3) then examined the relationship between movement patterns and trophic levels across individuals. The comparison focused on two adjacent (yet unconnected) subestuarine lake systems of varying levels of enrichment (Figure 1). The Alligator Creek system has elevated nutrient levels (eutrophic) compared to those of the McCormick Creek System (mesotrophic). We hypothesized that Common Snook in the enriched Alligator Creek system would exhibit different movement patterns relative to Snook in the mesotrophic McCormick Creek system. Nutrient enrichment is known to reduce overall species richness, while also frequently increasing the abundance and concentration of prey (Smith \& Schindler, 2008; Breitburg, 2002); thus, we hypothesized that Snook in the eutrophic system would exhibit less movement between habitats in 
response to an expected lower prey spatial variability produced by eutrophic conditions (Mueller \& Fagan, 2008, Breitburg, 2002). In contrast, we hypothesized that Snook in mesotrophic conditions would show a higher degree of movement between habitats, in order to track prey sources moving throughout the system. Furthermore, we hypothesized that Snook in the enriched Alligator Creek system would have less diverse basal resource use than those in the less enriched McCormick Creek system following the premise that the enrichment of aquatic systems often increases food web reliance on the algal pathway (Nelson et al. 2018).

\section{METHODOLOGY}

\subsection{Study System}

The lakes region in the northern rim of Florida Bay (Figure 1, $25.181664^{\circ} \mathrm{N}$, $80.764714^{\circ} \mathrm{W}$ ) is one of the most understudied, yet highly impacted areas in ENP. The region experiences pronounced enrichment, higher salinity regimes relative to predrainage conditions, and seasonal hypersalinity (in its lower reaches) caused by a chronic deficit in freshwater inputs (Fourqurean \& Robblee, 1999; Nuttle et al., 2000; Frankovich et al., 2011, 2012). The area consists of two parallel yet unconnected chains of lake systems. Each system has a single creek connecting the chain of lakes within it, and a single creek exit to relatively small embayments that empty into Florida Bay. Common Snook moving between systems must then exit and reenter each system via their respective exit creeks and these small southern embayments. The Alligator Creek system is composed of West, Cuthbert, and Long Lakes and the Lungs, and it opens to Garfield Bight via Alligator Creek. The McCormick Creek system is composed of Seven Palm, 
Middle and Monroe Lakes, and it opens to Terrapin Bay via McCormick Creek (Figure $1)$.

Differences in local geography between the lake systems affect the amounts of freshwater inflow and the degree of connectivity with Florida Bay (Frankovich et al., 2012). The Alligator Creek system is less hydrologically-connected with Florida Bay and experiences higher and seasonally-hypersaline salinity conditions, higher water column nutrient concentrations, persistent algal blooms, low light availability to the benthos, and less diverse SAV cover (Table A.1) than the McCormick Creek system. By contrast, the McCormick Creek system is better connected to Florida Bay and to freshwater inputs to the east, and is characterized by better water quality (i.e., lower nutrients and salinities, and higher light transparencies), and a more diverse SAV community, representing the historical pre-drainage conditions (Frankovich et al. 2011; 2012; 2017) than the Alligator Creek system. Both systems show north to south gradients in habitat conditions including nutrients, salinity, SAV cover and composition, and chlorophyll a levels (Table A.1). Using data from Frankovich et al. (2011), trophic state index values range from 5464 for the Alligator Creek system, and 40-44 for the McCormick system classifying the systems as eutrophic and mesotrophic respectively (Wetzel, 2001; Carlson, 1977). Hereafter, we refer to the Alligator Creek system as the eutrophic system, and to the McCormick system as the mesotrophic system.

The mechanisms driving the elevated nutrient levels in the study area are poorly understood, but three prevailing hypotheses have been proposed that may be operating solely or interacting. Reduced freshwater inflows caused by drainage and impoundment of the freshwater ecosystem likely reduced the flushing of nutrients from the eutrophic 
Alligator Creek system into Florida Bay, and increased water residence time that maintains nutrients within the system (Frankovich et al., 2011; 2012). The second hypothesis is that the enrichment of the eutrophic system is a result of a legacy effect from wading bird rookeries (particularly in Cuthbert Lake) and large waterfowl populations, both of which are presently only a small fraction of historical abundances (Ogden et al., 2014; Frankovich et al., 2011; 2012). Third, nutrients may be originating from groundwater discharges, resulting from saltwater intrusion inland, and associated desorption of phosphorus in contact with limestone rock (Flower et al., 2017).

\subsection{Snook Movement Tracking}

We tracked Common Snook (hereafter Snook) movements and habitat preferences in the two lake systems using acoustic telemetry; and in particular the Coastal Everglades Lakes Acoustic Array $\left(\mathrm{CELA}^{2}\right)$, consisting of 28 omnidirectional passive acoustic telemetry receivers (VR2W, VEMCO, Bedford, Nova Scotia, Canada, Figure 1). Snook locations are recorded when an acoustically-tagged fish swims within the detection range of an acoustic receiver. Each acoustic tag transmits a unique ultrasonic acoustic signal that receivers are able to detect, and record (tag identification, date, and time). Detection data were obtained by retrieving receivers and downloading detections using Vemco VUE software (via a Bluetooth connection) every three to four months.

The configuration of the acoustic receivers focused on tracking cross-lake movements and exits to embayments and Florida Bay to the south. Thus, receivers were strategically deployed at: a) 'choke' points located at creek mouths that designated entrances/exits to lakes, and b) at exit points to the southern bays (Garfield Bight and 
Terrapin Bay) and c) Florida Bay (Figure 1). The array did not contain enough receivers to track movement within lakes or bays. We used this deployment configuration focused on inter-lake or lake-to-bay movements to designate four zones of interest for tracking Snook distribution:

upstream, middle,

downstream and bay

(Figure 1, Table A.1).

The upstream zone

included the

uppermost lakes

(West and Cuthbert in

the eutrophic system,

and Seven Palm in the

mesotrophic system), while

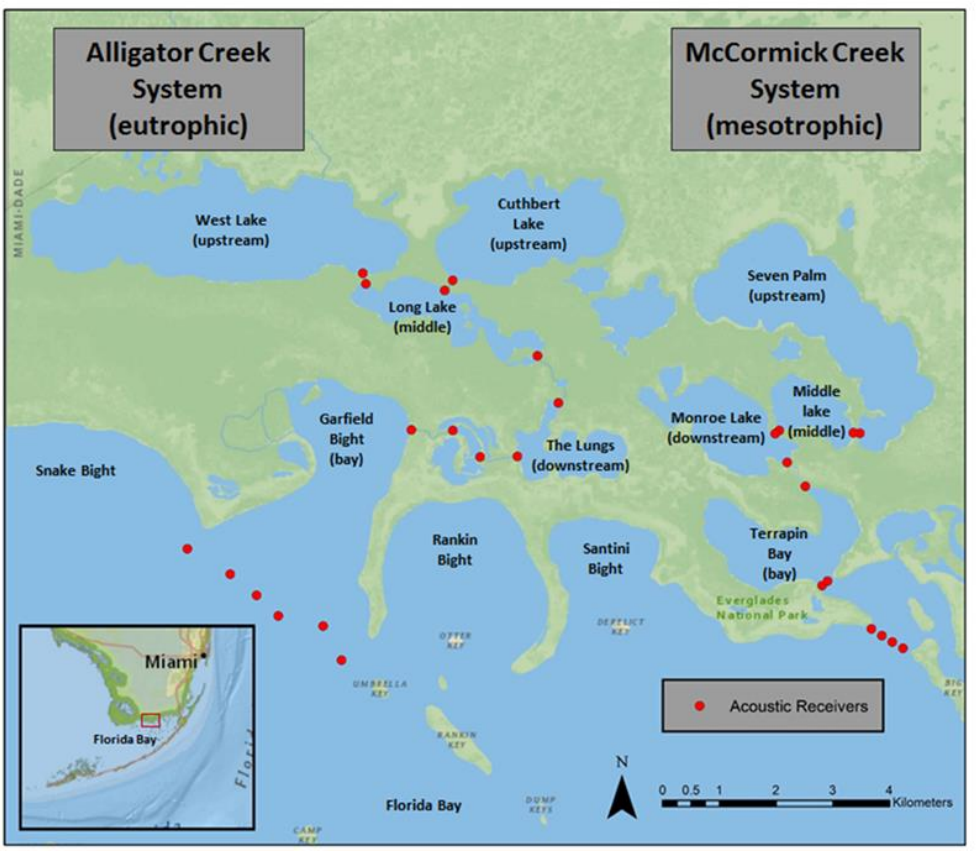

Figure 1. The Coastal Everglades Lakes Acoustic Array $\left(\mathrm{CELA}^{2}\right)$. Acoustic receivers (depicted in red) were placed at entry/exit points to lake systems and bays and exits to Florida Bay to track Snook movements across zones. The systems are adjacent to each other, but not connected (Snook have to exit one system and re-enter through Florida Bay to move between lake systems), and they vary in trophic state and related abiotic conditions (see Table A.1 for details) allowing for cross-site comparison.

the middle zone includes

Long and Middle Lakes in each system respectively. The downstream zone included The Lungs and Monroe Lake, and the bay zone encompassed Garfield Bight and Terrapin Bay. These zones captured north to south gradients in abiotic conditions, namely increasing salinities and SAV cover and diversity, as well as decreasing nutrient and chlorophyll $\alpha$ concentrations (Table A.1).

The array was deployed in the summer of 2016. Range testing using Vemco V13L test tags (10-second fixed delay) showed that receivers had better detection ranges in the creeks connecting lakes (300-500 m) than in the bays (50-100 m). Across all sites, 
test tags maintained an average reception efficiency $\geq 90 \%$ between 50 to $125 \mathrm{~m}$ (meaning that $90 \%$ of all transmitted signals within a 3-minute period were recorded by acoustic receivers), which was resemblant to those observed by Luo et al. (2009) in a similar environment (Biscayne Bay, FL) and deemed adequate for detecting tagged fish in our system. These differences in detection efficiency were most likely due to varied depth, bottom type, and SAV coverage (and associated soundscapes; Huveneers et al., 2016; Capello, 2015; Cotton, 2010). The two systems are not significantly influenced by tides, thus climate-related variation in detection ranges was suspected to relate to only wind-driven tidal variation.

\subsection{Snook Tagging and Sample Collection}

Common Snook are a subtropical, euryhaline species that inhabit estuarine systems from Florida to Brazil (Boucek et al., 2019; Blewett et al., 2006; Taylor, 2000). Common Snook are a diadromous, protandric hermaphrodite species that typically associate with estuarine mangrove habitats and riverine systems and are capable of growing to $1000 \mathrm{~mm}$ fork length and 21 years of age (Taylor, 2000; Marshall, 1958). As an important recreational species in Florida, the harvest of Common Snook is highly managed by both slot limits and seasonal closures (Muller et al. 2015). Snook also play an important ecological role as one of the key mesopredators in South Florida estuaries and are primarily piscivorous, but invertebrates such as shrimp, crayfish, and crabs also make up large portions of their diet (Blewett et al., 2017; Blewett et al., 2006; Boucek and Rehage 2013). 
A total of 25 Common Snook were captured using hook and line, and tagged during the study period of June 2016 to June 2017 (Figure A.2). Of these, 8 Snook were tagged in the eutrophic system, and 17 Snook were tagged in the mesotrophic system. Tagged Snook ranged from 523 to $765 \mathrm{~mm}$ total length and 1.1 to $4.2 \mathrm{~kg}$ in weight. Captured fish were surgically implanted with Vemco acoustic transmitters using methodologies described by Boucek et al. (2017). The Vemco V-13L acoustic transmitters were programed on low power with a $120 \mathrm{sec}$ nominal delay to prolong battery life (battery life expectancy was 1500 days). Signal strength was adequate for the $\mathrm{CELA}^{2}$ array configuration, and tagged fish were rarely not detected by adjacent receivers as they moved up and down the chain of lakes. Before surgically implanting acoustic tags, a small piece $(<5 \mathrm{~g})$ of anal fin tissue was removed from each tagged fish and placed on ice for SIA. Basal resources were also collected in both systems for SIA. Basal resources included the dominant submerged aquatic vegetation (SAV): Halodule wrightii, Ruppia maritima, Thalassia testudinum, and Chara hornemannii, epiphytes from all SAV, particulate organic matter and benthic microalgae. All basal resources were collected concurrently with fish tagging efforts. Samples were placed on ice following collection for later SIA processing.

\subsection{Laboratory Isotope Analysis}

Anal fin clip samples were immediately frozen upon returning from the field and remained frozen until processing. Basal resources were processed for SIA immediately following returning from the field, rinsed with deionized water, and epiphytes were removed from SAV using a razor blade. Anal fin clips were dried for 48 hours in a $50^{\circ} \mathrm{C}$ 
oven, ground using mortar and pestle, and weighed using a Mettler Toledo microbalance with a readability of $0.001 \mathrm{mg}$. Between 0.4 and $0.7 \mathrm{mg}$ of sample was placed in a $8 \times 5$ $\mathrm{mm}$ tin cup for $\delta^{15} \mathrm{~N}$ and $\delta^{13} \mathrm{C}$ analysis, and between 2.0 and $3.0 \mathrm{mg}$ of sample was placed in $5 \times 9 \mathrm{~mm}$ tin cups for $\delta^{34} \mathrm{~S}$ analysis. Samples were analyzed at the Stable Isotope Core Laboratory at Washington State University using standard element analyzer and isotope ratio mass spectrometer (IRMS) procedures. The results are presented with respect to the international standards of atmospheric nitrogen (air, $\mathrm{N}_{2}$ ) and Vienna PeeDee Belemnite (V-PDB) for carbon. The 2-sigma uncertainty of carbon isotopic results is 0.5 per milligram unless otherwise indicated. This means that if the same sample were resubmitted for isotopic analysis, the newly measured value would lay within the uncertainty bounds $95 \%$ of the time. All results are expressed using standard delta notation as parts per thousand (\%) with respect to reference standards. Anal fin SIA is expected to provide dietary information for a relatively short period of time (a few weeks to a couple of months; Matley et al., 2016).

\subsection{Movement Metrics}

We focused on two movement metrics to characterize the space use of Snook throughout the systems: inter-zone movement events and movement event duration. These two metrics were based on how tagged individuals used the designated four zones within each system (upstream, middle, downstream and bay, Figure 1). Inter-zone movement events were calculated by counting the unique visits to each zone (i.e., frequency of zone changes). Using the "choke point" design of the receiver array, we were able to track acoustically-tagged Snook as they moved between the different zones 
within each system and quantify the number of zone changes each Snook made. Leaving one zone and moving into another then constituted one inter-zone movement event (Figure A.1), and this inter-zone movement frequency provided a proxy of the mobility of Snook within each lake system. These movement events were summed separately by zone for each fish to obtain a total account of how a Snook used zones over its detection history. For example, Snook tag number 53352, had a total of 190 of inter-zone movement events over its 331-day detection history (in the mesotrophic system), with 78 events the upper zone, 60 in the middle zone, 36 in the downstream zone, and 16 in the bay.

Movement event duration was defined as the average cumulative time spent (i.e., hours) within each zone. The metric was calculated by compiling the elapsed times between the first and last detections for a given fish for a particular movement event within each zone (Figure A.1). We then averaged these across each zone to obtain the mean duration of an event across each of the four zones. For instance, for that same Snook 53352, the overall average duration of a movement event was $67 \mathrm{hrs}$, and the breakdown of their average event duration by zone was as follows: 50 hrs for the upper zone, $10 \mathrm{hrs}$ for the middle zone, 2 hrs for the downstream zone, and $206 \mathrm{hrs}$ for the bay. We considered movement event duration to be a proxy of habitat selection, possibly indicating more profitable foraging locations or preferred habitat because of suitable abiotic conditions (Kock et al., 2013; Reubens et al., 2013; Humston et al., 2005). 


\subsection{Data Analyses}

For both movement metrics, data were combined over the detection record of individuals to obtain a single value of each metric per Snook across zones and systems (i.e., a tag number $*$ system * zone matrix). As described above, inter-zone movement events were summarized by counting the total number of zone changes an individual made at each zone*system combination. Movement event duration was summarized by averaging the time an individual spent at each zone*system combination (Figure A.1). Then, the habitat use metrics were compared between systems and their zones using generalized linear mixed models (GLMMs) with a log link function, and a Poisson and Gaussian error distribution for inter-zone movement events and residence time, respectively. Snook individual tag IDs were incorporated as a random variable in the GLMMs to encompass variation among individuals. The Akaike information criterion (AIC) was used for model selection and R2 using penalized quasi-likelihood estimation was used as measure of goodness-of-fit for models (Jaeger et al. 2017). When the best model included significant interaction terms, a Tukey Post hoc test was performed to assess pairwise differences among the zone*system interactions.

Bayesian mixing models were run in R version 3.4.2 (R Core Team, 2017) using the package MixSIAR (Stock et al., 2018) to determine the relative basal resource contributions to each individual Snook in each system. Each model was run with a Markov chain Monte Carlo algorithm that consisted of three chains, chain length of 100,000 , burn-in of 50,000, and thin of 50 to ensure model convergence. Corrections were made for the elemental concentration in each source and trophic enrichment for each element, $\mathrm{C}=1.3 \pm 0.3, \mathrm{~N}=2.9 \pm 0.5$, and $\mathrm{S}=0.3 \pm 0.1$ (mean $\pm \mathrm{SD}$; Phillips et al., 
2014). From the mixing model results, trophic level (TL) was calculated using the equation:

Equation (1):

$$
T L=\frac{\delta^{15} N_{c o n}-\sum\left(\delta^{15} N_{s} * f_{s}\right)}{\Delta \delta^{15} N}+1
$$

where $\Delta \delta^{15} \mathrm{~N}=2.9$ is the trophic enrichment factor for nitrogen (Hussey et al., 2014; Post, 2002), $\delta^{15} \mathrm{~N}_{\text {con }}$ is the $\delta^{15} \mathrm{~N}$ consumer (Snook) value, $\delta^{15} \mathrm{~N}_{s}$ is the $\delta^{15} \mathrm{~N}$ value of each basal resource, and $f_{s}$ is the contribution of each basal resource to the consumer diet (Nelson et al., 2015). A one-way ANOVA was used to test for differences in the mean trophic level between the eutrophic and mesotrophic systems.

The movement metrics were related to the trophic level (TL) estimated from the mixing model using GLMs. We specifically examined the significance of the TL*Zone interaction term in the GLM since we were interested in testing if and how the isotopic content of individuals explain a proportion of the variation of Snook habitat use. We acknowledge that a major limitation of relating trophic and movement variables in this study and others (e.g., Harrison et al. 2017, Matich and Heithaus, 2014; Carlisle et al., 2012) is the temporal offset of the data. Isotopic values reflect short-term diets over weeks to months prior to capture (Matley et al., 2016; Matich et al. 2017), while the movement data are collected after capture and expand up to a year's time. All data analyses were performed in R v3.2.5 (R Core Team 2017). The GLM and the Tukey Post hoc test were performed with the stats (R Core Team 2017) and multcomp (Hothorn et al. 2008) R packages respectively. 


\section{RESULTS}

\subsection{Snook Detections}

Snook detection histories over our one-year study for the 25 tagged Snook ranged from 13 to 365 days, with a mean of 216 days of detection (Figure A.2). Over $50 \%$ of tagged Snook were detected within the system at any given time. We observed minimal inter-system movement, with 23 Snook showing movements only within one lake system, and only two fish (tags 53345 and 53338) detected in both systems (Figure A.2). Snook 53345 was originally tagged in the mesotrophic system, but over $80 \%$ of its total time detected was in the eutrophic system. Snook 53338 was also originally tagged in the mesotrophic system and had about a 50\% split in detections between systems. Both of these Snook were still classified as mesotrophic system fish for all SIA since the isotopic values obtained from their fin clips represent what the fish had been consuming weeks to months prior to capture (Matich et al., 2017, Matley et al., 2016). Their movement metrics however, were scored and analyzed separately in the two systems.

\subsection{Variation in Movement Metrics}

Snook moved differently across lake systems and zones. Model selection showed that inter-zone movements were best explained by the system*zone interaction, while for movement event duration, the best model was a systems model (Table 1). The model selection analysis also showed that we were able to explain a higher proportion of the variance in the movement events than in the event duration. For the movement events, Snook from the mesotrophic system had more inter-zone movement events, and shorter movement event durations than Snook from the eutrophic system (Figure 2a-b \& Table 


\section{1). In particular, these mesotrophic Snook exhibited higher numbers of inter-zone}

Table 1. Results of model selection including the generalized linear mixed models (GLMM) considered to assess variance in the two movement metrics. A) inter-zone movement events and b) movement event duration. For both metrics, the models included system (eutrophic vs. mesotrophic) and zone (upstream, middle, downstream, and bay) and their interaction. Shown are the number of estimated parameters, second-order Akaike information criterion (AICc), difference in AICc score among listed model and best AICc, AIC weights, $\log$-likelihood, and generalized $\mathrm{R}^{2}$ (standardized measure of multivariate association between the fixed predictors and the observed values). Bold values indicate best fitting models. For b) movement event duration, we selected the model with the highest AICc due to lack of convergence demonstrated by the other models.

\begin{tabular}{|c|c|c|c|c|c|c|c|c|}
\hline Variable & Model & $\begin{array}{c}\text { Estimated } \\
\text { Parameters }\end{array}$ & $\mathrm{AICc}$ & Delta AICc & $\begin{array}{c}\text { Relative } \\
\text { Model } \\
\text { Likelihood }\end{array}$ & $\begin{array}{c}\text { AlCc } \\
\text { Weights }\end{array}$ & $\begin{array}{l}\text { Log- } \\
\text { Likelihood }\end{array}$ & $\begin{array}{c}\text { Generalized } \\
\mathbf{R}^{2}\end{array}$ \\
\hline \multirow{3}{*}{$\begin{array}{l}\text { a) Inter-Zone } \\
\text { Movement } \\
\text { Events }\end{array}$} & SystemZone & 9 & 3179.36 & 0.00 & $1.00 \mathrm{E}+00$ & $1.00 \mathrm{E}+00$ & -1580.21 & 0.28 \\
\hline & System & 6 & 3449.60 & 270.23 & $2.09 \mathrm{E}-59$ & $2.09 \mathrm{E}-59$ & -1718.58 & 0.23 \\
\hline & Zone & 5 & 4968.08 & 1788.72 & $0.00 \mathrm{E}+00$ & $0.00 E+00$ & -2478.89 & 0.12 \\
\hline \multirow{3}{*}{$\begin{array}{l}\text { b) Movement } \\
\text { Event Duration }\end{array}$} & SystemZone ${ }^{1}$ & 10 & 1479.97 & 0.00 & $1.00 \mathrm{E}+00$ & $1.00 E+00$ & -728.64 & 0.07 \\
\hline & Zone $^{1}$ & 6 & 1528.03 & 48.06 & $3.66 \mathrm{E}-11$ & $3.66 \mathrm{E}-11$ & -757.53 & 0.12 \\
\hline & System & 4 & 1554.39 & 74.42 & $6.91 \mathrm{E}-17$ & $6.91 \mathrm{E}-17$ & -772.97 & 0.09 \\
\hline
\end{tabular}

1Model failed to converge

movement events in the upstream and middle zones. These mesotrophic Snook had an average of 30 movement events in the upstream and middle zones, compared to less than 20 movement events in the downstream and bay zones (Figure 2c). In contrast, inter-zone movement events in the eutrophic system were much lower. On average, eutrophic Snook had less than 7 movement events over the detection history, with the least number of events occurring in the upstream zone, and the highest number in the downstream zonethe opposite pattern seen for mesotrophic Snook.

For movement event duration, we saw longer movement events in the eutrophic system (Table 1). On average, movement event durations lasted $247 \mathrm{hrs}$ ( 10 days) in the eutrophic system, relative to $56 \mathrm{hrs}$ ( 2 days) in the mesotrophic system (Figure $2 \mathrm{~b}$ ).

Even though the selected model for event duration only considered a system effect due to a lack of convergence of the other models (despite a lower AICc for the system*zone model, Table 1), we note that there was a tendency for Snook to have higher event 
durations, indicating longer stays and thus higher residency, in the upstream and bay

zones for both systems relative to the other two zones (Figure 2d). This suggests a

similar pattern of residency for Snook across the zones in the two systems, but the

duration of these 'stays' was about 5 times longer in the eutrophic system.
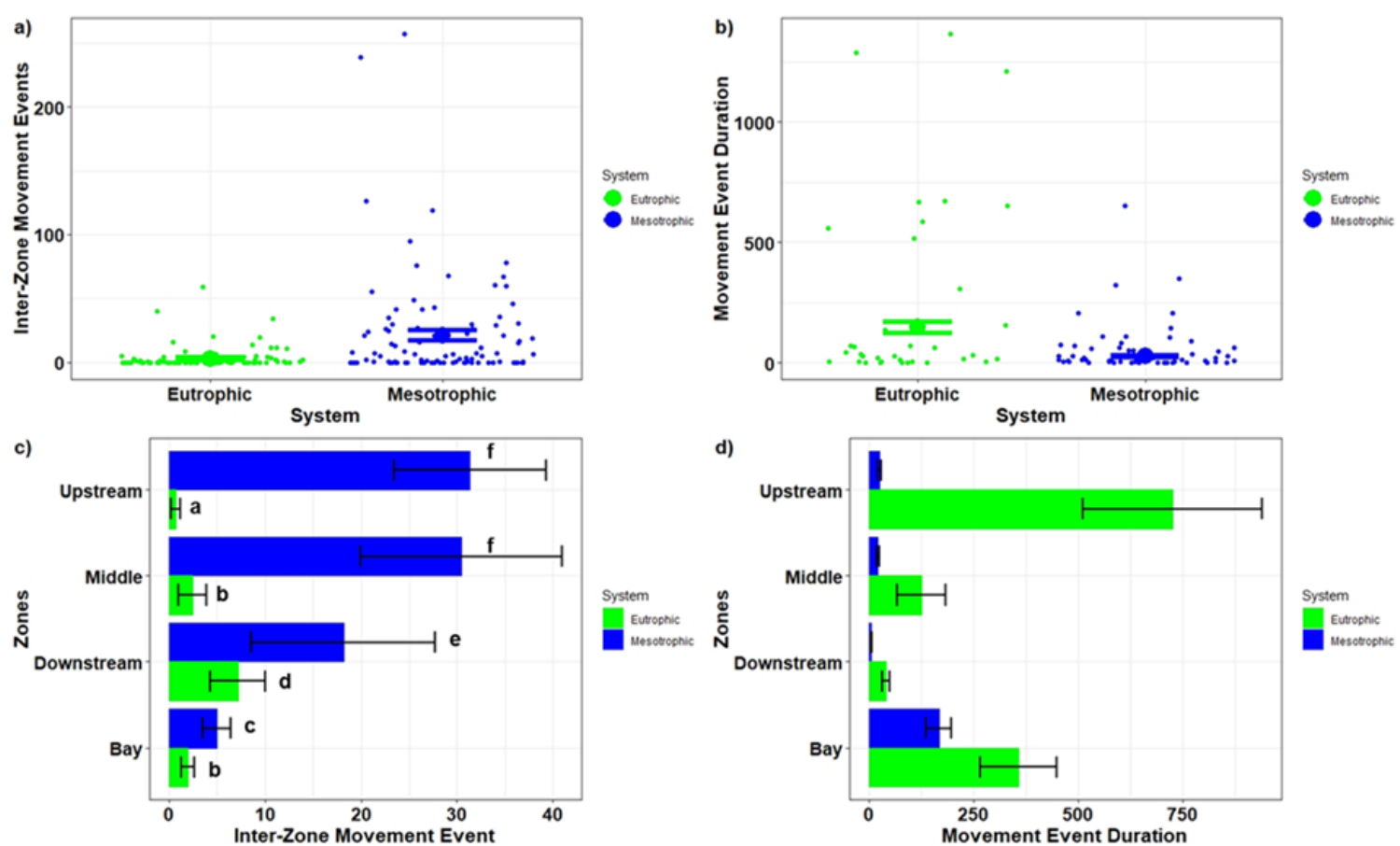

Figure 2. Habitat use metrics for Snook across zones and the two focal lake systems, eutrophic and mesotrophic and for zones within each system. Shown are a) inter-zone movement events (counts) and b) duration of movement events (hours) for Snook across the eutrophic and mesotrophic systems. Also shown is the comparison of c) movement events and d) duration of movement events across zones in each system. The letters in c) denote significant differences among means. Snook had higher movement events in the mesotrophic system, but lower event durations relative to the eutrophic system, suggesting higher mobility in the mesotrophic system, and this mobility was highest in the upper zones. We saw a trend for higher event duration at the uppermost and lowermost zones, particularly in the eutrophic system, suggesting higher residency of Snook in these areas.

\subsection{Variation in Basal Resources and Trophic Level}

The mixing model results revealed that Snook collected from the eutrophic system used a broader range of basal resources than Snook from the mesotrophic system

(Figures 3 and 4a, Table 2). None of the Snook in the eutrophic system used more than 0.25 of any basal resource, with Chara $(0.22 \pm 0.01$, mean \pm SD), benthic microalgae 
$(0.20 \pm 0.03)$, and Ruppia epiphytes $(0.16 \pm 0.02)$ being the three most used basal

resources. The Snook in the mesotrophic system primarily used Chara epiphytes $(0.48 \pm$ $0.02)$, and particulate organic matter from the water column $(0.18 \pm 0.03)$. All other basal
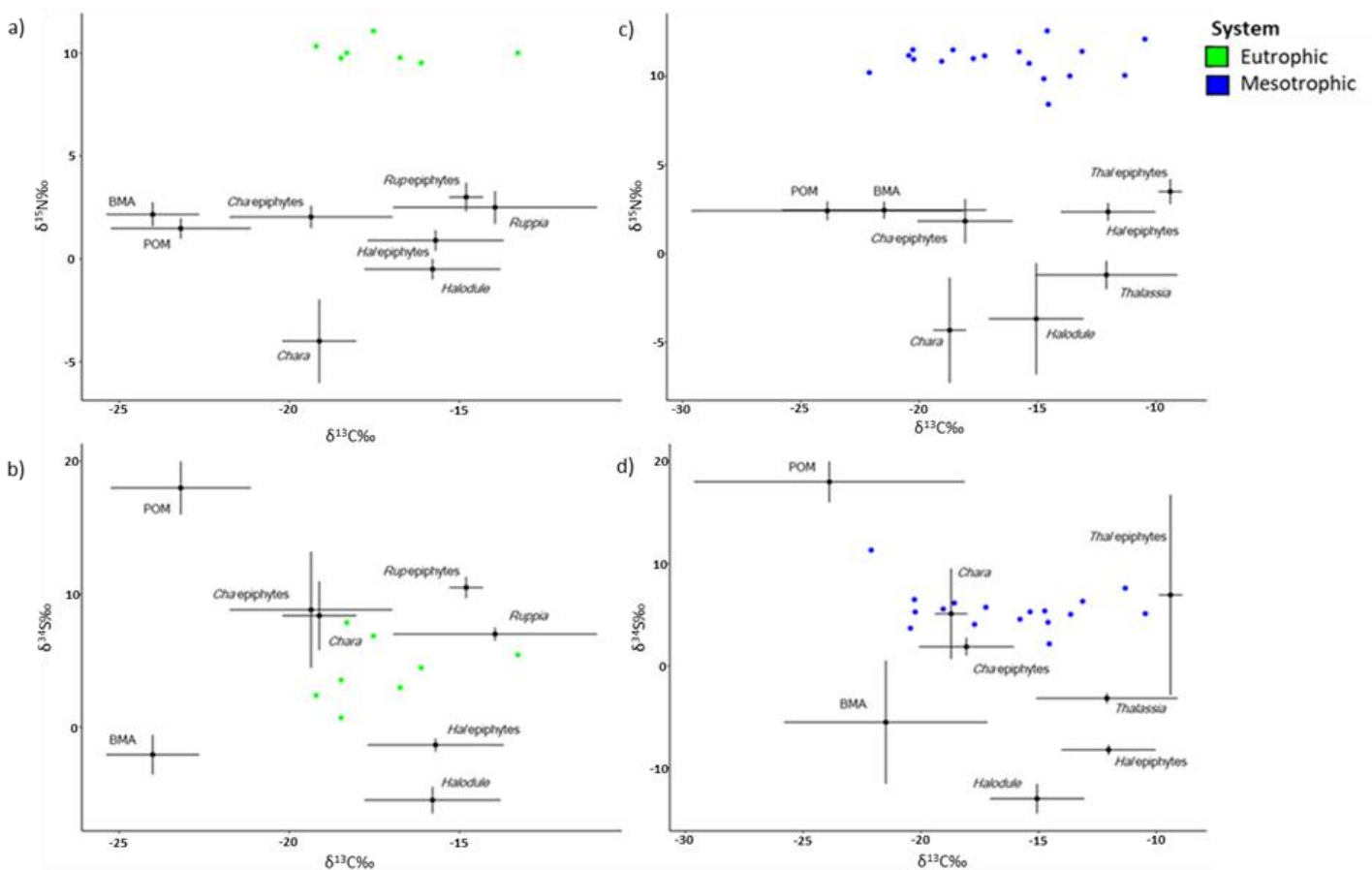

Figure 3. Stable isotope biplots of basal resources for each system. Black symbols with lines indicate standard deviations and the colored symbols represent the 25 Snook. Shown are $\delta^{15} \mathrm{~N}$ versus $\delta^{13} \mathrm{C}$ of Snook in the a) eutrophic and b) mesotrophic systems; and $\delta^{34} \mathrm{~S}$ versus $\delta^{13} \mathrm{C}$ of Snook in the c) eutrophic and d) mesotrophic systems. Biplots show that no basal resources are missing in the analysis of Snook in our study. Abbreviations for basal resources are as follows: Hal = Halodule wrightii, Rup= Ruppia maritima, Cha $=$ Chara hornemannii, Thal $=$ Thalassia testudinum, $\mathrm{POM}=$ particulate organic matter and BMA $=$ benthic microalgae .

resources were less than 0.1 (Table 2, Figure 4a). There was no significant difference in the trophic level of Snook across systems (Figure $4 b, F_{1,23}=0.14, p=0.71$ ); however, Snook in mesotrophic system did show a greater range in trophic position (3.4-4.5) than Snook in the eutrophic system (4.0-4.6).

\subsection{Relating Movement to Resource Use}

When relating movement metrics to the output of the mixing model, we only found a significant relationship between inter-zone movement events and Snook trophic 
level (Figure 5, Table 3). Higher trophic level Snook elicited more inter-zone movement events in the downstream and middle zones, but had less inter-zone movement events in the upstream zones (Figure 5a, Table A.2). Event duration across zones did not show

\begin{tabular}{|c|c|c|}
\hline Sources & Eutrophic System & Mesotrophic System \\
\hline BMA & $0.195 \pm 0.03$ & $0.043 \pm 0.01$ \\
\hline Chara & $0.215 \pm 0.01$ & $0.053 \pm 0.01$ \\
\hline Chara epiphytes & $0.083 \pm 0.01$ & $0.484 \pm 0.02$ \\
\hline Halodule & $0.075 \pm 0.01$ & $0.052 \pm 0.01$ \\
\hline Halodule epiphytes & $0.097 \pm 0.01$ & $0.052 \pm 0.01$ \\
\hline POM & $0.048 \pm 0.01$ & $0.177 \pm 0.03$ \\
\hline Ruppia & $0.124 \pm 0.01$ & NA \\
\hline Ruppia epiphytes & $0.163 \pm 0.02$ & NA \\
\hline Thalassia & NA & $0.055 \pm 0.01$ \\
\hline Thalassia epiphytes & NA & $0.085 \pm 0.01$ \\
\hline Trophic level & $4.23 \pm 0.17$ & $4.27 \pm 0.33$ \\
\hline
\end{tabular}

clear trends as a function of trophic level (Figure 5b, Table 3). We did not observe any other significant relationships between Snook resource use and our movement metrics, which we attribute to relatively low inter-individual variation in resource use across our 25 Snook (Figure 4a).

\section{DISCUSSION}

Nutrient enrichment can affect the behaviors, abundance, and distributions of prey, as well as the abiotic conditions throughout foraging landscapes, and thus have a major influence on the habitat use and distribution of consumers (Roberts et al. 2009; 
Vanerploeg et al., 2009; Keister et al., 2000). The present study, we examined the relationship between Snook movement and space use patterns, as well as trophic characteristics in a coastal

habitat with varying

nutrient enrichment levels.

We observed variation in

both movement and resource

use of Snook between the

eutrophic Alligator Creek

system and the mesotrophic

\section{McCormick Creek}

b)

system. Snook moved

more in mesotrophic

system, and the

majority of these

movements took place

in the upstream reaches

of the system. In contrast, in

the eutrophic system, we

observed longer movement

event durations suggesting

higher residency for Snook,
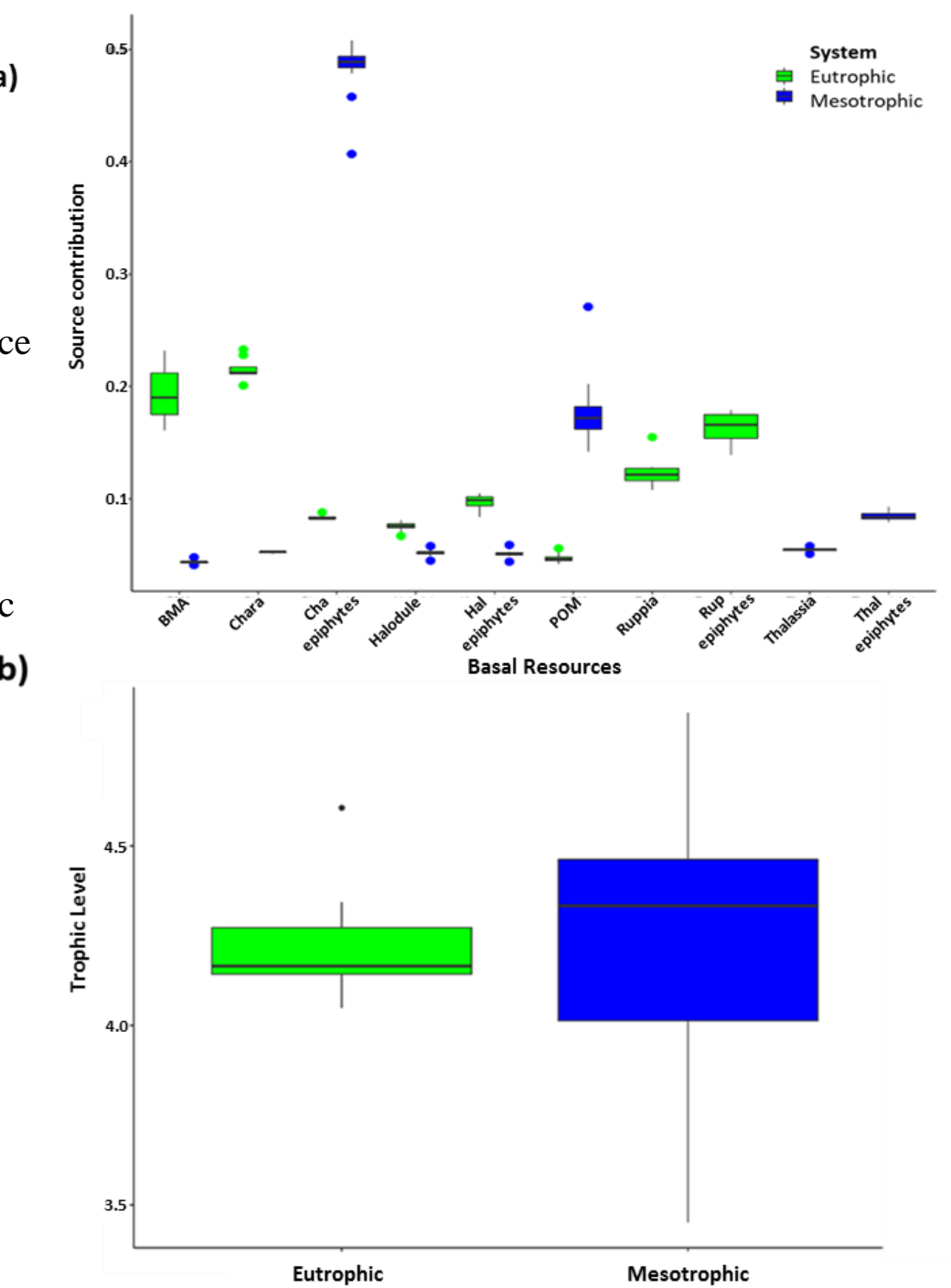

Figure 4. Boxplots of the source contributions to Snook and trophic level determined by MixSIAR. a) Boxplots of the source contributions to Snook. Snook in the eutrophic system have more diverse source contributions than those in the mesotrophic system. b) Boxplots of the trophic levels of Snook in the eutrophic and mesotrophic systems. For box plots, bars = median, boxes $=$ interquartile range $($ low $=25$ th percentile, upper $=75$ th percentile $)$, whiskers $=$ largest value within 1.5 time interquartile range below the 25 th or above the 75th percentiles. Abbreviations for basal resources are as follows: Hal $=$ Halodule wrightii, Rup $=$ Ruppia maritima, $\mathrm{Cha}=$ Chara hornemannii, Thal $=$ Thalassia testudinum, $\mathrm{POM}=$ particulate organic matter and BMA = benthic microalgae. Results show no trophic level difference between Snook in the two systems and more variation in mesotrophic system.

with a trend for this higher residency to occur at opposite ends of the eutrophic system 
(the upstream and bay zones). Stable isotope analyses revealed no difference in trophic level between eutrophic and mesotrophic Snook, but rather that basal source contributions were more varied in Snook in the eutrophic system relative to the mesotrophic. Finally, trophic level and movement were related, but the relationship was zone-dependent. Higher trophic level Snook elicited more inter-zone movement events in the downstream and middle zones but had lower movement events in the upstream zones. Overall, our findings emphasize the importance of the patch-scale (e.g., zones) to both the movement and the foraging ecology of our focal consumer.

Table 3. Summary of results for the analysis of deviance for the generalized linear models (GLM) used to assess variation in a) interzone movement events and b) movement event duration as function of trophic level (TL) and zones. Shown are model degree of freedom (Df), deviance, residual degree of freedom (Resid.Df), residual deviance (Resid.Dev), and the estimated p-value associated with the $\chi^{2}$ (Chi-squared) $(\mathrm{P}(>|\mathrm{Chi}|)$. Bold text identifies significant improvement between the models and the null model at $\alpha=0.05$.

\begin{tabular}{|c|c|c|c|c|c|c|c|}
\hline Movement Metric & Term & Df & Deviance & Resid.Df & Resid.Dev & $\operatorname{Pr}(>C h i)$ & $\begin{array}{l}\text { Deviance } \\
\text { Explained }\end{array}$ \\
\hline \multirow{4}{*}{ a) Inter-Zone Movement Events } & Null & & & 199 & $7.43 E+03$ & & \multirow{4}{*}{0.08} \\
\hline & $\mathrm{TL}$ & 1 & 0.22 & 198 & $7.43 E+03$ & 6.37E-01 & \\
\hline & Zone & 3 & 558.3 & 195 & $6.88 \mathrm{E}+03$ & 2.20E-16 & \\
\hline & TL:Zone & 3 & 43.7 & 192 & $6.83 E+03$ & $1.76 \mathrm{E}-09$ & \\
\hline \multirow{4}{*}{ b) Movement Event Duration } & Null & & & 92 & $6.72 E+06$ & & \multirow{4}{*}{0.16} \\
\hline & $\mathrm{TL}$ & 1 & 66752 & 91 & $6.66 \mathrm{E}+06$ & $3.15 E-01$ & \\
\hline & Zone & 3 & 934742 & 88 & $5.72 E+06$ & 2.73E-03 & \\
\hline & TL:Zone & 3 & 99677 & 85 & $5.62 E+06$ & 6.81E-01 & \\
\hline
\end{tabular}

\subsection{Variation in Snook Movement and Residency}

Consumer movements determine an organism's habitat domain or the spatial extent of area that an individual uses, which is relevant to interspecific interactions such as foraging (Schmitz et al., 2017), and can have major implications for the stability of those interactions (McCann et al., 2005). Animal movement is expected to be governed by the interactions of the internal state, motion capacity, and navigation capacity of the individual with externals factors (Nathan et al., 2008). Among relevant external factors, 
resource distribution, abiotic conditions, landscape configuration, predation risk, and intraspecific/social interactions should affect the extent of movement and the overall pattern of space use of consumers (e.g., Gil et al., 2018; Kohl et al., 2018; Dodge et al., 2014; Avgar et al., 2013). We hypothesized that variation in Snook movement metrics across the meso and eutrophic systems resulted as a function of three main mechanisms: a) variation in resources landscapes, b) hypoxia associated with enrichment, and c) geomorphological features of the systems of study, and we discuss each of these in following paragraphs.
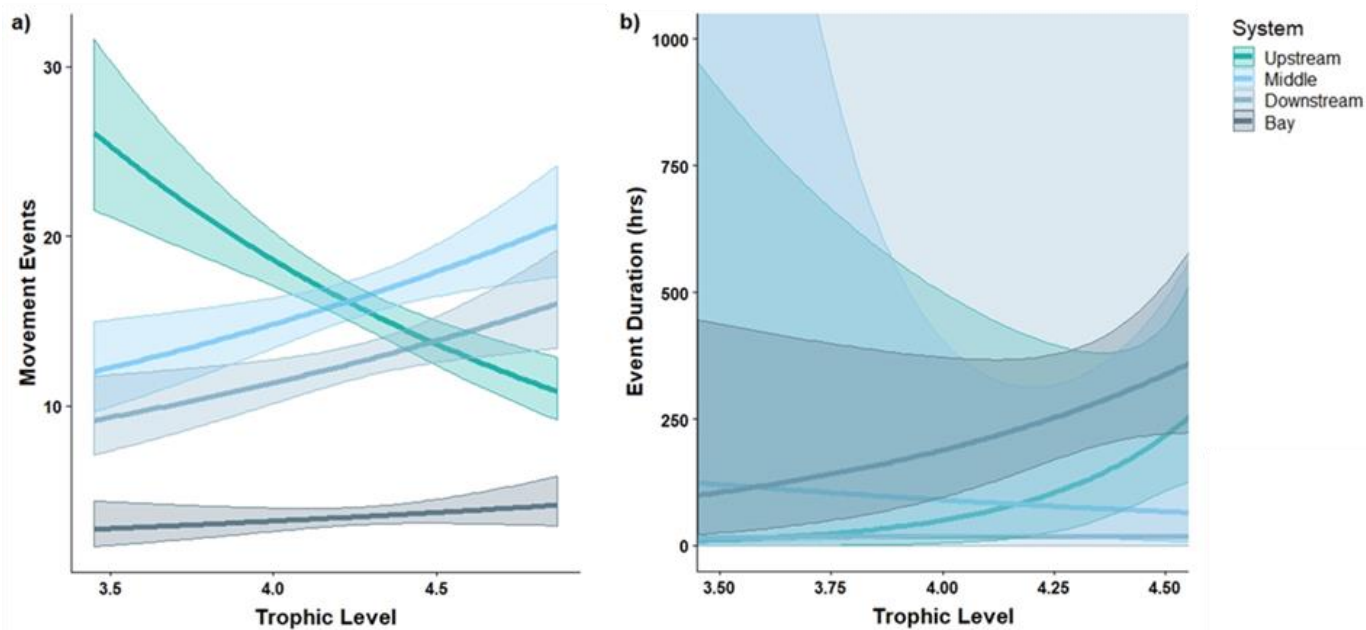

Figure 5. Fit of generalized linear models (GLMs) to assess the relationships between Snook trophic level. A) inter-zone movement events and b) movement event duration, separately by zone (combined for both systems). See Table 3 for more details on the GLMs.

First, if resources are patchily-distributed, we may expect, as suggested by optimal foraging theory, that consumers spend more time in areas where prey are more abundant in order to maximize energy intake, and that they depart from these profitable patches when expected energy gains drop below those of other patches (Charnov, 1976). In accordance with optimality, previous theoretical and empirical work suggests that consumer movement rates should increase when resource patches are more 
heterogeneous (Mueller \& Fagan, 2008; De Knegt et al., 2007), and, at the same time, they should decrease when consumers travel through high resource patches (Avgar et al., 2013; Owen-Smith et al., 2010; Pyke et al., 1977). If our system fits these previous studies, the higher frequency of inter-zone movement events observed in the mesotrophic system would suggest that prey distribution is patchier here relative to the eutrotrophic system. Similarly, the higher movement event durations (or residency) of Snook in the eutrophic system would suggest that patches in this system may be of higher quality. Preliminary prey data for the study period (2016-2017) showed similar prey communities across the two systems (e.g., Lucania parva, Microgobius gulosus, Floridichthys carpio, Eucinostomus spp., and Anchoa spp.), but further analyses are needed to determine the degree of prey patchiness across systems, and how Snook movement patterns may track this patchiness.

Second, a key mechanism affecting distributional patterns related to enrichment involves hypoxia (i.e., low concentrations of dissolved oxygen; Roberts et al. 2009; Vanderploeg et al., 2009; Keister et al., 2000). In our system, data from South Florida Water Management District shows that hypoxia occurs routinely in portions of the upstream zone of the eutrophic system during summer months. Hypoxic events resulting in a fish kill, that included Snook mortalities, were also observed in the middle and downstream zones of the eutrophic system over the course of the study (Eggenberger, pers. obs.). Hypoxic conditions could have both direct effects on Snook movement and space use, and/or indirect effects via effects on their prey. Snook are a dissolved oxygen (DO)-dependent species that are intolerant of low DO at sizes $>150 \mathrm{~mm}$ (Peterson and Gilmore, 1991). Hypoxic events may be driving the observed low Snook mobility in the 
eutrophic system, and possibly be trapping Snook in DO tolerable portions of the upstream zone of this system (as told by the highest movement event durations or residency observed in the eutrophic upstream zone). Hypoxia can also alter the abundance and distribution of prey, often leading to more heterogeneous and patchy prey distributions (Craig and Crowder, 2005; McKinsey and Chapman, 1998; Kramer, 1987). Much of Snook prey are intolerant to low DO, but some species such as Striped Mullet (Mugil cephalus) can behaviorally adjust to low DO conditions (Stevens et al., 2010; Cech \& Wohlschlag, 1973). Although prey have been known to exploit low DO conditions in order to avoid predation (Altieri, 2008), nutrient enrichment in the eutrophic system may be increasing prey abundance, but this effect may be only observed outside of the hypoxic-vulnerable zones (Breitburg, 2002) and may explain the longer movement event durations observed in the bay zones. More detailed information on DO spatiotemporal dynamics, which is the subject of ongoing work, is needed to comprehensively assess this hypothesis of the influence of DO on Snook movement both as a function of, and independent of, prey density and distribution effects.

A third but perhaps lesser consideration driving variation in Snook movement across systems and zones is the differential geomorphology and thus spatial configuration of the two systems. The eutrophic system is slightly larger than the mesotrophic system, and travel costs associated with foraging (e.g., travel time, Charnov, 1976) may differ between systems. These slightly longer distances that Snook have to travel between lakes in the eutrophic system could be influencing the observed lower movements and higher movement event durations in that system. Further, these higher travel cost could also be 
influenced by the interaction of greater distances and the summer hypoxia experienced in the eutrophic system.

\subsection{Trophic Variation Across Systems}

Nutrient enrichment is known to reduce overall species richness, while also frequently increasing the abundance and concentrations of prey (Smith \& Schindler, 2008;

Breitburg, 2002). Yet, Snook in the eutrophic system showed more varied basal source contributions than those in the mesotrophic system, suggesting that eutrophic system Snook are possibly relying on a higher diversity of prey. Optimal foraging theory predicts that as resource availability decreases, consumers are forced to depend on non-preferred, less profitable prey due to increased competition, and as a result, consumer resource use is broadened (Calizza et al., 2017; Pyke et al., 1977). For example, Calizza et al. (2017) found that resource use by invertebrate consumers expanded in degraded seagrass patches due to the lower abundance of resources and increased competition, and as a consequence, they relied on lower quality resources (as determined by SIA). This could explain the increased resource contributions observed in the eutrophic Snook.

Conversely, another potential explanation of the more varied basal resource contributions observed in the eutrophic system may involve hypoxia. The hypoxic events in the eutrophic system may act as a form of habitat fragmentation (i.e., by constraining the space that could be used by this highly mobile species) and restrict foraging to particular habitat patches that have suitable DO conditions. We expect existing gradients in environmental conditions (per Table A.1) to drive variation in prey landscapes and thus the foraging behavior of Snook. A consumer's SIA values reflect those of the 
habitats in which they live and feed (e.g., Calizza et al., 2017), and if Snook in the eutrophic system are restricted to feeding in patches composed of very different prey at opposite ends of the eutrophic system (upstream and bay zones), it could explain the broader resource use observed. This would be congruent with the findings of previous work where habitat fragmentation caused resource contributions to expand in a livebearing fish species in the Bahamas (Araújo et al., 2014).

\subsection{Coupling of Movement and Trophic Patterns}

Various studies have shown how movement metrics coupled with SIA could be critical to disentangling how environmental factors influence species interactions, and thus the resulting foraging strategies that animals manifest across space and time (Harrison et al. 2017; Matich \& Heithaus, 2014; Papastamatiou et al., 2010; Cunjak et al., 2005). Snook are primarily opportunistic ambush predators (Blewett et al., 2013), but the zone-dependent nature of the relationship between trophic level and movement suggests that Snook may be exhibiting variable foraging strategies and/or prey selection across zones. Fish species are known to be capable of altering their foraging strategies as habitat profitabilities change (Warburton, 2003). For example, Northern Pike, Esox lucius, foraging strategies shift based on the turbidity of the waters they inhabit (Anderson et al., 2008). These shifting foraging strategies can then of course alter the movement and trophic patterns of focal consumers. For instance, Harrison et al. (2017) found significant amounts of variation in Burbot (Lota lota) stable isotopes and movement due to differences in foraging strategies, with individuals who fed more piscivorously moving at higher rates and relying more on pelagic prey. It is then plausible that Snook are shifting 
their foraging patterns in order to optimally forage along the north to south gradients that exist in our lake systems tracking SAV cover/composition, salinity, nutrient concentrations, and/or Chlorophyll $\alpha$ gradients, and expected associated changes in prey numbers, quality and availability. This could explain the trend why higher trophic level Snook move less upstream, but more in the middle and downstream zones of the systems. The differential mobility of Snook should have important consequences for the stability of food webs in these two systems. Theoretical work by McCann et al. (2005) predicts that mobile consumers couple multiple subsystems and habitats and can have a stabilizing effect at regional scales (bounding consumer densities away from low values and resulting in less variable dynamics). In contrast, if consumer mobility is low or constrained by anthropogenic effects (e.g., habitat fragmentation or hypoxia) and food webs are compressed, consumers only couple local habitats, leading to stronger top down effects and trophic cascades, as well as an overall destabilizing effect on food webs due to runaway consumption, and the synchronization of resources by consumers. For instance, lake trout are expected to impose stronger top-down effects in smaller lakes, and as result become increasingly omnivorous (Vander Zander et al., 1999). Based on these predictions, we may expect differential levels of top down effects in our system, with higher top down effects in the eutrophic system relative to the mesotrophic system. This prediction is consistent with our finding of broader resource use in the eutrophic system, possibly reflecting inclusion of more prey types in the diet of Snook and these expected stronger top down effects. 


\section{CONCLUSION}

Cross-site comparison studies that bridge the disciplines of movement ecology and trophic ecology have the potential to increase our understanding of how various mechanisms drive animal behavior at multiple spatial scales, and of the consequences of varying movement patterns for food web dynamics and energy transfer in ecosystems. Our findings demonstrate that consumer movements can vary with changing environmental conditions at small scales, highlighting the need to incorporate both movement and trophic information to determine how animals adjust their habitat use under varying environmental conditions and production regimes. The results also enhance our understanding of how freshwater management (and associated eutrophication effects) can have cascading effects on the habitat quality, distribution and foraging of economically-valuable recreational fish species such as Snook. Overall, this work highlights the importance of incorporating both movement and trophic information when determining how multiple mechanisms may be impacting the habitat selection of organisms over space and time. 


\section{REFERENCES}

Altieri, A. H. (2008). Dead zones enhance key fisheries species by providing predation refuge. Ecology, 89(10), 2808-2818.

Andersen, M., Jacobsen, L., Grønkjær, P., \& Skov, C. (2008). Turbidity increases behavioural diversity in northern pike, Esox lucius L., during early summer.

Fisheries Management and Ecology, 15(5-6), 377-383.Avgar, T., Mosser, A., Brown, G. S., \& Fryxell, J. M. (2013).

Araújo, M. S., Langerhans, R. B., Giery, S. T., \& Layman, C. A. (2014). Ecosystem fragmentation drives increased diet variation in an endemic livebearing fish of the Bahamas. Ecology and Evolution, 4(16), 3298-3308.

Avgar, T., Mosser, A., Brown, G. S., \& Fryxell, J. M. (2013). Environmental and individual drivers of animal movement patterns across a wide geographical gradient. Journal of Animal Ecology, 82(1), 96-106.

Blewett, D. A., Stevens, P. W., \& Carter, J. (2017). Ecological effects of river flooding on abundance and body condition of a large, euryhaline fish. Marine Ecology Progress Series, 563, 211-218.

Blewett, D. A., Hensley, R. A., \& Stevens, P. W. (2006). Feeding habits of common snook, Centropomus undecimalis, in Charlotte Harbor, Florida. Gulf and Caribbean Research, 18(1), 1-14.

Blewett, D. A., Stevens, P. W., \& Call, M. E. (2013). Comparative ecology of euryhaline and freshwater predators in a subtropical floodplain river. Florida Scientist, 166-190.

Block, W. M., \& Brennan, L. A. (1993). The habitat concept in ornithology. In Current ornithology (pp. 35-91). Springer, Boston, MA.

Boucek, R. E., \& Morley, D. (2019). Demonstrating the value of cross-ecosystem syntheses and comparisons in animal movement and acoustic telemetry research. Fisheries Research

Boucek, R. E., Trotter, A. A., Blewett, D. A., Ritch, J. L., Santos, R., Stevens, P. W., ... \& Rehage, J. (2019). Contrasting river migrations of Common Snook between two Florida rivers using acoustic telemetry. Fisheries Research, 213, 219-225.

Boucek, R. E., Heithaus, M. R., Santos, R., Stevens, P., \& Rehage, J. S. (2017). Can animal habitat use patterns influence their vulnerability to extreme climate events? An estuarine sportfish case study. Global change biology, 23(10), 4045-4057. 
Boucek, R., Leone, E., Walters-Burnsed, S., Bickford, J., \& Lowerre-Barbieri, S. (2017). More than just a spawning location: examining fine scale space use of two estuarine fish species at a spawning aggregation site. Frontiers in Marine Science, 4, 355.

Boucek, R. E., \& Rehage, J. S. (2013). No free lunch: displaced marsh consumers regulate a prey subsidy to an estuarine consumer. Oikos, 122(10), 1453-1464.

Boyer, J. N., Fourqurean, J. W., \& Jones, R. D. (1997). Spatial characterization of water quality in Florida Bay and Whitewater Bay by multivariate analyses: zones of similar influence. Estuaries and Coasts, 20(4), 743-758.

Breitburg, D. L., Craig, J. K., Fulford, R. S., Rose, K. A., Boynton, W. R., Brady, D. C., ... \& Hart, D. R. (2009). Nutrient enrichment and fisheries exploitation: interactive effects on estuarine living resources and their management. Hydrobiologia, 629(1), 31-47.

Breitburg, Denise. "Effects of hypoxia, and the balance between hypoxia and enrichment, on coastal fishes and fisheries." Estuaries 25.4 (2002): 767-781.

Brönmark, C., \& Miner, J. G. (1992). Predator-induced phenotypical change in body morphology in crucian carp. Science, 258(5086), 1348-1350.

Brown, C. E., Bhat, M. G., Rehage, J. S., Mirchi, A., Boucek, R., Engel, V., ... \& Sukop, M. (2018). Ecological-economic assessment of the effects of freshwater flow in the Florida Everglades on recreational fisheries. Science of the Total Environment, 627, 480493.

Capello, M., Robert, M., Soria, M., Potin, G., Itano, D., Holland, K., ... \& Dagorn, L. (2015). A methodological framework to estimate the site fidelity of tagged animals using passive acoustic telemetry. PloS one, 10(8), e0134002.

Carlisle, A. B., Kim, S. L., Semmens, B. X., Madigan, D. J., Jorgensen, S. J., Perle, C. R., ... \& Block, B. A. (2012). Using stable isotope analysis to understand the migration and trophic ecology of northeastern Pacific white sharks (Carcharodon carcharias). PloS one, $7(2)$, e30492.

Carlson, R. E. (1977). A trophic state index for lakes. Limnology and oceanography, 22(2), 361-369.

Cech Jr, J. J., \& Wohlschlag, D. E. (1973). Respiratory responses of the striped mullet, Mugil cephalus (L.) to hypoxic conditions. Journal of Fish Biology, 5(4), 421-428.

Charnov, E. L. (1976). Optimal foraging, the marginal value theorem. Cotton, C. F. (2010). Factors affecting reception range of ultrasonic tags in a Georgia estuary. Marine Technology Society Journal, 44(5), 17-24. 
Craig, J. K., \& Crowder, L. B. (2005). Hypoxia-induced habitat shifts and energetic consequences in Atlantic croaker and brown shrimp on the Gulf of Mexico shelf. Marine Ecology Progress Series, 294, 79-94.

Cunjak, R. A., Roussel, J. M., Gray, M. A., Dietrich, J. P., Cartwright, D. F., Munkittrick, K. R., \& Jardine, T. D. (2005). Using stable isotope analysis with telemetry or markrecapture data to identify fish movement and foraging. Oecologia, 144(4), 636-646.

De Knegt, H. J., Hengeveld, G. M., Van Langevelde, F., De Boer, W. F., \& Kirkman, K. P. (2007). Patch density determines movement patterns and foraging efficiency of large herbivores. Behavioral Ecology, 18(6), 1065-1072.

Dodge, S., Bohrer, G., Bildstein, K., Davidson, S. C., Weinzierl, R., Bechard, M. J., ... \& Wikelski, M. (2014). Environmental drivers of variability in the movement ecology of turkey vultures (Cathartes aura) in North and South America. Philosophical Transactions of the Royal Society B: Biological Sciences, 369(1643), 20130195.

Donaldson, M. R., Hinch, S. G., Suski, C. D., Fisk, A. T., Heupel, M. R., \& Cooke, S. J. (2014). Making connections in aquatic ecosystems with acoustic telemetry monitoring. Frontiers in Ecology and the Environment, 12(10), 565-573.

Flower, H., Rains, M., Lewis, D., Zhang, J. Z., \& Price, R. (2017). Saltwater intrusion as potential driver of phosphorus release from limestone bedrock in a coastal aquifer. Estuarine, Coastal and Shelf Science, 184, 166-176.

Fourqurean, J. W., \& Robblee, M. B. (1999). Florida Bay: a history of recent ecological changes. Estuaries, 22(2), 345-357. Frankovich, T. A., Barr, J. G., Morrison, D., \& Fourqurean, J. W. (2012). Differing temporal patterns of Chara hornemannii cover correlate to alternate regimes of phytoplankton and submerged aquatic-vegetation dominance. Marine and Freshwater Research, 63(11), 1005-1014.

Frankovich, T. A., Morrison, D., \& Fourqurean, J. W. (2011). Benthic macrophyte distribution and abundance in estuarine mangrove lakes and estuaries: relationships to environmental variables. Estuaries and coasts, 34(1), 20-31.

Frankovich, T. A., Barr, J. G., Morrison, D., \& Fourqurean, J. W. (2012). Differing temporal patterns of Chara hornemannii cover correlate to alternate regimes of phytoplankton and submerged aquatic-vegetation dominance. Marine and Freshwater Research, 63(11), 1005-1014.

Frankovich, T. A., Rudnick, D. T., \& Fourqurean, J. W. (2017). Light attenuation in estuarine mangrove lakes. Estuarine, Coastal and Shelf Science, 184, 191-201.

Fretwell, S. D., \& Lucas, H. L. (1969). On territorial behavior and other factors influencing habitat distribution in birds. Acta biotheoretica, 19(1), 16-36. 
Gallagher, A. J., Creel, S., Wilson, R. P., \& Cooke, S. J. (2017). Energy landscapes and the landscape of fear. Trends in ecology \& evolution, 32(2), 88-96.

Gil, M. A., Hein, A. M., Spiegel, O., Baskett, M. L., \& Sih, A. (2018). Social information links individual behavior to population and community dynamics. Trends in ecology \& evolution.

Hammerschlag-Peyer, C. M., \& Layman, C. A. (2010). Intrapopulation variation in habitat use by two abundant coastal fish species. Marine Ecology Progress Series, 415, 211-220.

Hall, Q.A., Curtis, J.M., Williams, J., Stunz G.W. (2019) The importance of newlyopened tidal inlets as spawning corridors for adult Red Drum (Sciaenops ocellatus). Fisheries Research.

Harrison, P. M., Gutowsky, L. F. G., Martins, E. G., Ward, T. D., Patterson, D. A., Cooke, S. J., \& Power, M. (2017). Individual isotopic specializations predict subsequent inter-individual variation in movement in a freshwater fish. Ecology, 98(3), 608-615.

Hothorn, T., Bretz, F., \& Westfall, P. (2008). Simultaneous inference in general parametric models. Biometrical journal, 50(3), 346-363.

Humston, R., Ault, J. S., Larkin, M. F., \& Luo, J. (2005). Movements and site fidelity of the bonefish Albula vulpes in the northern Florida Keys determined by acoustic telemetry. Marine Ecology Progress Series, 291, 237-248.

Hussey, N. E., Kessel, S. T., Aarestrup, K., Cooke, S. J., Cowley, P. D., Fisk, A. T., ... \& Flemming, J. E. M. (2015). Aquatic animal telemetry: a panoramic window into the underwater world. Science, 348(6240), 1255642.

Hussey, N. E., MacNeil, M. A., McMeans, B. C., Olin, J. A., Dudley, S. F., Cliff, G., ... \& Fisk, A. T. (2014). Rescaling the trophic structure of marine food webs. Ecology letters, 17(2), 239-250.

Huveneers, C., Simpfendorfer, C. A., Kim, S., Semmens, J. M., Hobday, A. J., Pederson, H., \& Peddemors, V. (2016). The influence of environmental parameters on the performance and detection range of acoustic receivers. Methods in Ecology and Evolution, 7(7), 825-835.

Jaeger, B. C., Edwards, L. J., Das, K., \& Sen, P. K. (2017). An R 2 statistic for fixed effects in the generalized linear mixed model. Journal of Applied Statistics, 44(6), 10861105. 
Kays, R., Crofoot, M. C., Jetz, W., \& Wikelski, M. (2015). Terrestrial animal tracking as an eye on life and planet. Science, 348(6240), aaa2478.

Keister, J. E., Houde, E. D., \& Breitburg, D. L. (2000). Effects of bottom-layer hypoxia on abundances and depth distributions of organisms in Patuxent River, Chesapeake Bay. Marine Ecology Progress Series, 205, 43-59.

Kelble, C. R., Johns, E. M., Nuttle, W. K., Lee, T. N., Smith, R. H., \& Ortner, P. B. (2007). Salinity patterns of Florida Bay. Estuarine, Coastal and Shelf Science, 71(1), 318-334.

Kock, A., O’Riain, M. J., Mauff, K., Meÿer, M., Kotze, D., \& Griffiths, C. (2013). Residency, habitat use and sexual segregation of white sharks, Carcharodon carcharias in False Bay, South Africa. PloS one, 8(1), e55048.

Kohl, M. T., Stahler, D. R., Metz, M. C., Forester, J. D., Kauffman, M. J., Varley, N., ... \& MacNulty, D. R. (2018). Diel predator activity drives a dynamic landscape of fear. Ecological Monographs, 88(4), 638-652.

Kramer, D. L. (1987). Dissolved oxygen and fish behavior. Environmental biology of fishes, 18(2), 81-92.

Lee, T. N., Melo, N., Smith, N., Johns, E. M., Kelble, C. R., Smith, R. H., \& Ortner, P. B. (2016). Circulation and water renewal of Florida Bay, USA. Bulletin of Marine Science, 92(2), 153-180.

Marshall, A. R. (1958). A survey of the snook fishery of Florida, with studies of the biology of the principal species, Centropomus undecimalis (Bloch). Fla. Board Conserv. Mar. Res. Lab. Tech. Ser, 22, 39.

Luo, J., Serafy, J. E., Sponaugle, S., Teare, P. B., \& Kieckbusch, D. (2009). Movement of gray snapper Lutjanus griseus among subtropical seagrass, mangrove, and coral reef habitats. Marine Ecology Progress Series, 380, 255-269.

Matich, P., Ault, J. S., Boucek, R. E., Bryan, D. R., Gastrich, K. R., Harvey, C. L., ... \& Rosenblatt, A. E. (2017). Ecological niche partitioning within a large predator guild in a nutrient-limited estuary. Limnology and Oceanography, 62(3), 934-953.

Matich, P., \& Heithaus, M. R. (2014). Multi-tissue stable isotope analysis and acoustic telemetry reveal seasonal variability in the trophic interactions of juvenile bull sharks in a coastal estuary. Journal of Animal Ecology, 83(1), 199-213.

Matley, J. K., Fisk, A. T., Tobin, A. J., Heupel, M. R., \& Simpfendorfer, C. A. (2016). Diet-tissue discrimination factors and turnover of carbon and nitrogen stable isotopes in 
tissues of an adult predatory coral reef fish, Plectropomus leopardus. Rapid Communications in Mass Spectrometry, 30(1), 29-44.

McCann, K. S., Rasmussen, J. B., \& Umbanhowar, J. (2005). The dynamics of spatially coupled food webs. Ecology letters, 8(5), 513-523.

McKinsey, D. M., \& Chapman, L. J. (1998). Dissolved oxygen and fish distribution in a Florida spring. Environmental Biology of Fishes, 53(2), 211-223.

Moore, F. R., \& Aborn, D. A. (2000). Mechanisms of en route habitat selection: How do migrants make habitat decisions during stopover?. Studies in Avian Biology, 20, 34-42.

Moss, B., Kosten, S., Meerhoff, M., Battarbee, R. W., Jeppesen, E., Mazzeo, N., .. \& Paerl, H. (2011). Allied attack: climate change and eutrophication. Inland waters, 1(2), 101-105.

Mueller, T., \& Fagan, W. F. (2008). Search and navigation in dynamic environmentsfrom individual behaviors to population distributions. Oikos, 117(5), 654-664.

Muller, R. G., Trotter, A.A., Stevens P.W. (2015). The 2015 stock assessment update of Common Snook, Centropomus undecimalis. Florida Fish and Wildlife Conservation Commission. Fish and Wildlife Research Institute, IHR, 4.

Nathan, R., Getz, W. M., Revilla, E., Holyoak, M., Kadmon, R., Saltz, D., \& Smouse, P. E. (2008). A movement ecology paradigm for unifying organismal movement research. Proceedings of the National Academy of Sciences, 105(49), 19052-19059.

Nelson, J. A., Deegan, L., \& Garritt, R. (2015). Drivers of spatial and temporal variability in estuarine food webs. Marine Ecology Progress Series, 533, 67-77.

Nelson, J. A., Johnson, D. S., Deegan, L. A., Spivak, A. C., \& Sommer, N. R. (2018). Feedbacks Between Nutrient Enrichment and Geomorphology Alter Bottom-Up Control on Food Webs. Ecosystems, 1-14.

Nestlerode, J. A., \& Diaz, R. J. (1998). Effects of periodic environmental hypoxia on predation of a tethered polychaete, Glycera americana: implications for trophic dynamics. Marine Ecology Progress Series, 172, 185-195.

Nuttle, W. K., Fourqurean, J. W., Cosby, B. J., Zieman, J. C., \& Robblee, M. B. (2000). Influence of net freshwater supply on salinity in Florida Bay. Water Resources Research, $36(7), 1805-1822$.

Oberdorff, T., Pont, D., Hugueny, B., \& Chessel, D. (2001). A probabilistic model characterizing fish assemblages of French rivers: a framework for environmental assessment. Freshwater Biology, 46(3), 399-415. 
Ogden, J. C., Baldwin, J. D., Bass, O. L., Browder, J. A., Cook, M. I., Frederick, P. C., ... \& Oberhofer, L. D. (2014). Waterbirds as indicators of ecosystem health in the coastal marine habitats of southern Florida: 1 . Selection and justification for a suite of indicator species. Ecological indicators, 44, 148-163.

Owen-Smith, N., Fryxell, J. M., \& Merrill, E. H. (2010). Foraging theory upscaled: the behavioural ecology of herbivore movement. Philosophical Transactions of the Royal Society B: Biological Sciences, 365(1550), 2267-2278.

Papastamatiou, Y. P., Friedlander, A. M., Caselle, J. E., \& Lowe, C. G. (2010). Longterm movement patterns and trophic ecology of blacktip reef sharks (Carcharhinus melanopterus) at Palmyra Atoll. Journal of Experimental Marine Biology and Ecology, 386(1-2), 94-102.

Peterson, M. S., \& Gilmore, G. R. (1991). Eco-physiology of juvenile snook Centropomus undecimalis (Bloch): life-history implications. Bulletin of Marine Science, 48(1), 46-57.

Phillips, D. L., Inger, R., Bearhop, S., Jackson, A. L., Moore, J. W., Parnell, A. C., ... \& Ward, E. J. (2014). Best practices for use of stable isotope mixing models in food-web studies. Canadian Journal of Zoology, 92(10), 823-835.

Pihl, L., Baden, S. P., Diaz, R. J., \& Schaffner, L. C. (1992). Hypoxia-induced structural changes in the diet of bottom-feeding fish and Crustacea. Marine Biology, 112(3), 349361.

Post, D. M. (2002). Using stable isotopes to estimate trophic position: models, methods, and assumptions. Ecology, 83(3), 703-718.

Pyke, G. H., Pulliam, H. R., \& Charnov, E. L. (1977). Optimal foraging: a selective review of theory and tests. The quarterly review of biology, 52(2), 137-154.

Reubens, J. T., Pasotti, F., Degraer, S., \& Vincx, M. (2013). Residency, site fidelity and habitat use of Atlantic cod (Gadus morhua) at an offshore wind farm using acoustic telemetry. Marine Environmental Research, 90, 128-135.

Roberts, J. J., Höök, T. O., Ludsin, S. A., Pothoven, S. A., Vanderploeg, H. A., \& Brandt, S. B. (2009). Effects of hypolimnetic hypoxia on foraging and distributions of Lake Erie yellow perch. Journal of Experimental Marine Biology and Ecology, 381, S132-S142.

Rosenblatt, A. E., \& Heithaus, M. R. (2011). Does variation in movement tactics and trophic interactions among American alligators create habitat linkages?. Journal of Animal Ecology, 80(4), 786-798. 
Schmitz, O. J., Buchkowski, R. W., Smith, J. R., Telthorst, M., \& Rosenblatt, A. E. (2017). Predator community composition is linked to soil carbon retention across a human land use gradient. Ecology, 98(5), 1256-1265.

Smith, V. H., \& Schindler, D. W. (2009). Eutrophication science: where do we go from here?. Trends in ecology \& evolution, 24(4), 201-207.

Stephens, D. W., \& Krebs, J. R. (1986). Foraging theory. Princeton University Press.

Stevens, P. W., Blewett, D. A., Champeau, T. R., \& Stafford, C. J. (2010). Posthurricane recovery of riverine fauna reflected in the diet of an apex predator. Estuaries and Coasts, 33(1), 59-66.

Stevens, P. W., Boucek, R. E., Trotter, A. A., Ritch, J. L., Johnson, E. R., Shea, C. P., ... \& Rehage, J. S. (2018). Illustrating the value of cross-site comparisons: Habitat use by a large, euryhaline fish differs along a latitudinal gradient. Fisheries Research, 208, 42-48.

Stock, B. C., Jackson, A. L., Ward, E. J., Parnell, A. C., Phillips, D. L., \& Semmens, B. X. (2018). Analyzing mixing systems using a new generation of Bayesian tracer mixing models (No. e26884v1). PeerJ Preprints.

Taylor, R. G., Whittington, J. A., Grier, H. J., \& Crabtree, R. E. (2000). Age, growth, maturation, and protandric sex reversal in common snook, Centropomus undecimalis, from the east and west coasts of South Florida. Fishery Bulletin, 98(3), 612-612.

Vander Zanden, M. J., Shuter, B. J., Lester, N., \& Rasmussen, J. B. (1999). Patterns of food chain length in lakes: a stable isotope study. The American Naturalist, 154(4), 406416.

Warburton, K. (2003). Learning of foraging skills by fish. Fish and Fisheries, 4(3), 203 215.

Werner, E. E., \& Hall, D. J. (1974). Optimal foraging and the size selection of prey by the bluegill sunfish (Lepomis macrochirus). Ecology, 55(5), 1042-1052.

Wetzel, R.G. (2001). Limnology: Lake and river ecosystems ( $3^{\text {rd }}$ ed.) San Diego: Academic Press, an imprint of Elsevier.

Wolf, M., \& Weissing, F. J. (2012). Animal personalities: consequences for ecology and evolution. Trends in ecology \& evolution, 27(8), 452-461.

Vanderploeg, H. A., Ludsin, S. A., Ruberg, S. A., Höök, T. O., Pothoven, S. A., Brandt, S. B., ... \& Cavaletto, J. F. (2009). Hypoxia affects spatial distributions and overlap of pelagic fish, zooplankton, and phytoplankton in Lake Erie. Journal of Experimental Marine Biology and Ecology, 381, S92-S107. 


\section{APPENDIX}

Table A.1 Summary of habitat conditions across zones in the eutrophic Alligator Creek and mesotrophic McCormick Creek systems systems. Shown are mean salinity, nutrient, chlorophyll $\alpha$ and submerged aquatic vegetation (SAV) cover and composition across zones over the time period of this study (June 2016 to June 2017). Salinity, SAV cover, nutrients, and chl $\alpha$ concentrations are all higher in the eutrophic system and gradients are presents across zones. Shown are also the number of receivers by zone and system.

\begin{tabular}{|c|c|c|c|c|c|c|c|c|}
\hline $\begin{array}{c}\text { System \& } \\
\text { Lakes }\end{array}$ & Zone & $\begin{array}{l}\text { \# of } \\
\text { receivers }\end{array}$ & $\begin{array}{l}\text { Salinity } \\
\text { (PSU) }\end{array}$ & $\begin{array}{c}\text { Total } \\
\text { Nitrogen } \\
\text { (uM) }\end{array}$ & $\begin{array}{c}\text { Total } \\
\text { Phosphorus } \\
\text { (uM) }\end{array}$ & $\begin{array}{l}\text { Chlorophyll } \\
\qquad \alpha \text { (ug/L) }\end{array}$ & $\begin{array}{l}\% \text { SAV } \\
\text { Cover }\end{array}$ & $\begin{array}{l}\text { SAV Composition } \\
\text { (Dominant taxa) }\end{array}$ \\
\hline \multicolumn{9}{|c|}{ Alligator Creek system (eutrophic) } \\
\hline West Lake & Upstream & 1 & 14.8 & 156.3 & 1.6 & 10.4 & 28.2 & Chara hornemannii \\
\hline Cuthbert Lake & Upstream & 1 & 11.2 & 153.4 & 3.4 & 29.4 & 14.4 & Chara hornemannii \\
\hline Long Lake & Middle & 3 & 23.3 & 162.2 & 2.2 & 15.7 & 37.6 & Chara hornemannii \\
\hline The Lungs & Downstream & 4 & 27.6 & 176.7 & 2 & 9.9 & 73.1 & Chara hornemannii \\
\hline Garfield Bight & Bay & 7 & 35.1 & 104 & 1.3 & 11.7 & 61.3 & $\begin{array}{l}\text { Halodule wrightii \& } \\
\text { Batophora oestedii }\end{array}$ \\
\hline \multicolumn{9}{|c|}{ McCormick Creek system (mesotrophic) } \\
\hline 7 Palm & Upstream & 1 & 13.4 & 95.4 & 1.4 & 9.5 & 4.3 & $\begin{array}{l}\text { Halodule wrightii \& } \\
\text { Chara hornemannii }\end{array}$ \\
\hline Middle Lake & Middle & 2 & 16.0 & 101.5 & 1.3 & 7.6 & 7.4 & Halodule wrightii \\
\hline Monroe Lake & Downstream & 2 & 22.5 & 95.7 & 1.1 & 5.3 & 16.5 & Halodule wrightii \\
\hline Terrapin Bay & Bay & 7 & 32.8 & 84.3 & 0.7 & 1.3 & 27.2 & $\begin{array}{l}\text { Halodule wrightii, } \\
\text { Thalassia testudinum, } \\
\text { Batophora oerstedii, } \\
\text { LMM* }\end{array}$ \\
\hline
\end{tabular}

*LMM= lesser marine macroalgae 
Table A.2 List of coefficients (Coef) associated with each term included in the generalized linear models (GLMs) performed for each bi-combination of isotopes used to explain variance in the Snook movement metrics (response variables: inter-zone movement events). Shown are coefficient estimates, standard errors (Std.Error), $z$-values for the coefficient estimates for the null hypothesis of no difference, and the $\mathrm{P}(>|\mathrm{Z}|)$ for each GLM.

\begin{tabular}{|c|c|c|c|c|}
\hline System*Zone Comparison & Estimate & Std.Error & Z-value & $P(>|Z|)$ \\
\hline Mesotrophic.Bay - Eutrophic.Bay & 0.94 & 0.17 & 5.57 & 5.59E-07 \\
\hline Eutrophic.Downstream - Eutrophic.Bay & 1.30 & 0.16 & 8.09 & $6.11 \mathrm{E}-15$ \\
\hline Mesotrophic.Downstream - Eutrophic.Bay & 2.23 & 0.15 & 14.84 & $0.00 \mathrm{E}+00$ \\
\hline Eutrophic.Middle - Eutrophic.Bay & 0.24 & 0.19 & 1.23 & $9.03 \mathrm{E}-01$ \\
\hline Mesotrophic.Middle - Eutrophic.Bay & 2.74 & 0.15 & 18.66 & $0.00 \mathrm{E}+00$ \\
\hline Eutrophic.Upstream - Eutrophic.Bay & -1.00 & 0.27 & -3.64 & 4.75E-03 \\
\hline Mesotrophic.Upstream - Eutrophic.Bay & 2.77 & 0.15 & 18.87 & $0.00 \mathrm{E}+00$ \\
\hline Eutrophic.Downstream - Mesotrophic.Bay & 0.36 & 0.12 & 3.14 & $2.82 \mathrm{E}-02$ \\
\hline Mesotrophic.Downstream - Mesotrophic.Bay & 1.29 & 0.10 & 12.80 & $0.00 \mathrm{E}+00$ \\
\hline Eutrophic.Middle - Mesotrophic.Bay & -0.70 & 0.15 & -4.52 & $1.38 \mathrm{E}-04$ \\
\hline Mesotrophic.Middle - Mesotrophic.Bay & 1.81 & 0.10 & 18.76 & $0.00 \mathrm{E}+00$ \\
\hline Eutrophic.Upstream - Mesotrophic.Bay & -1.94 & 0.25 & -7.71 & $9.83 \mathrm{E}-14$ \\
\hline Mesotrophic.Upstream - Mesotrophic.Bay & 1.84 & 0.10 & 19.11 & $0.00 \mathrm{E}+00$ \\
\hline Mesotrophic.Downstream - Eutrophic.Downstream & 0.93 & 0.09 & 10.53 & $0.00 \mathrm{E}+00$ \\
\hline Eutrophic.Middle - Eutrophic.Downstream & -1.07 & 0.15 & -7.26 & $4.20 \mathrm{E}-12$ \\
\hline Mesotrophic.Middle - Eutrophic.Downstream & 1.44 & 0.08 & 17.44 & $0.00 \mathrm{E}+00$ \\
\hline Eutrophic.Upstream - Eutrophic.Downstream & -2.30 & 0.25 & -9.34 & $0.00 \mathrm{E}+00$ \\
\hline Mesotrophic.Upstream - Eutrophic.Downstream & 1.47 & 0.08 & 17.85 & $0.00 \mathrm{E}+00$ \\
\hline Eutrophic.Middle - Mesotrophic.Downstream & -1.99 & 0.14 & -14.74 & $0.00 \mathrm{E}+00$ \\
\hline Mesotrophic.Middle - Mesotrophic.Downstream & 0.52 & 0.06 & 8.73 & $0.00 \mathrm{E}+00$ \\
\hline Eutrophic.Upstream - Mesotrophic.Downstream & -3.23 & 0.24 & -13.46 & $0.00 \mathrm{E}+00$ \\
\hline Mesotrophic.Upstream - Mesotrophic.Downstream & 0.55 & 0.06 & 9.29 & $0.00 \mathrm{E}+00$ \\
\hline Mesotrophic.Middle - Eutrophic.Middle & 2.51 & 0.13 & 19.03 & $0.00 \mathrm{E}+00$ \\
\hline Eutrophic.Upstream - Eutrophic.Middle & -1.24 & 0.27 & -4.63 & $5.61 \mathrm{E}-05$ \\
\hline Mesotrophic.Upstream - Eutrophic.Middle & 2.54 & 0.13 & 19.28 & $0.00 \mathrm{E}+00$ \\
\hline Eutrophic.Upstream - Mesotrophic.Middle & -3.74 & 0.24 & -15.74 & $0.00 \mathrm{E}+00$ \\
\hline Mesotrophic.Upstream - Mesotrophic.Middle & 0.03 & 0.05 & 0.59 & $9.99 \mathrm{E}-01$ \\
\hline Mesotrophic.Upstream - Eutrophic.Upstream & 3.77 & 0.24 & 15.87 & $0.00 \mathrm{E}+00$ \\
\hline
\end{tabular}


Figure A.1 Conceptual diagram of how movement metrics were calculated using a hypothetical example detection history for Fish A. Movement metrics were calculated for each fish*zone*system combination.

\section{Example of inter-zone movement event (ME) and movement event duration (MED) calculations}
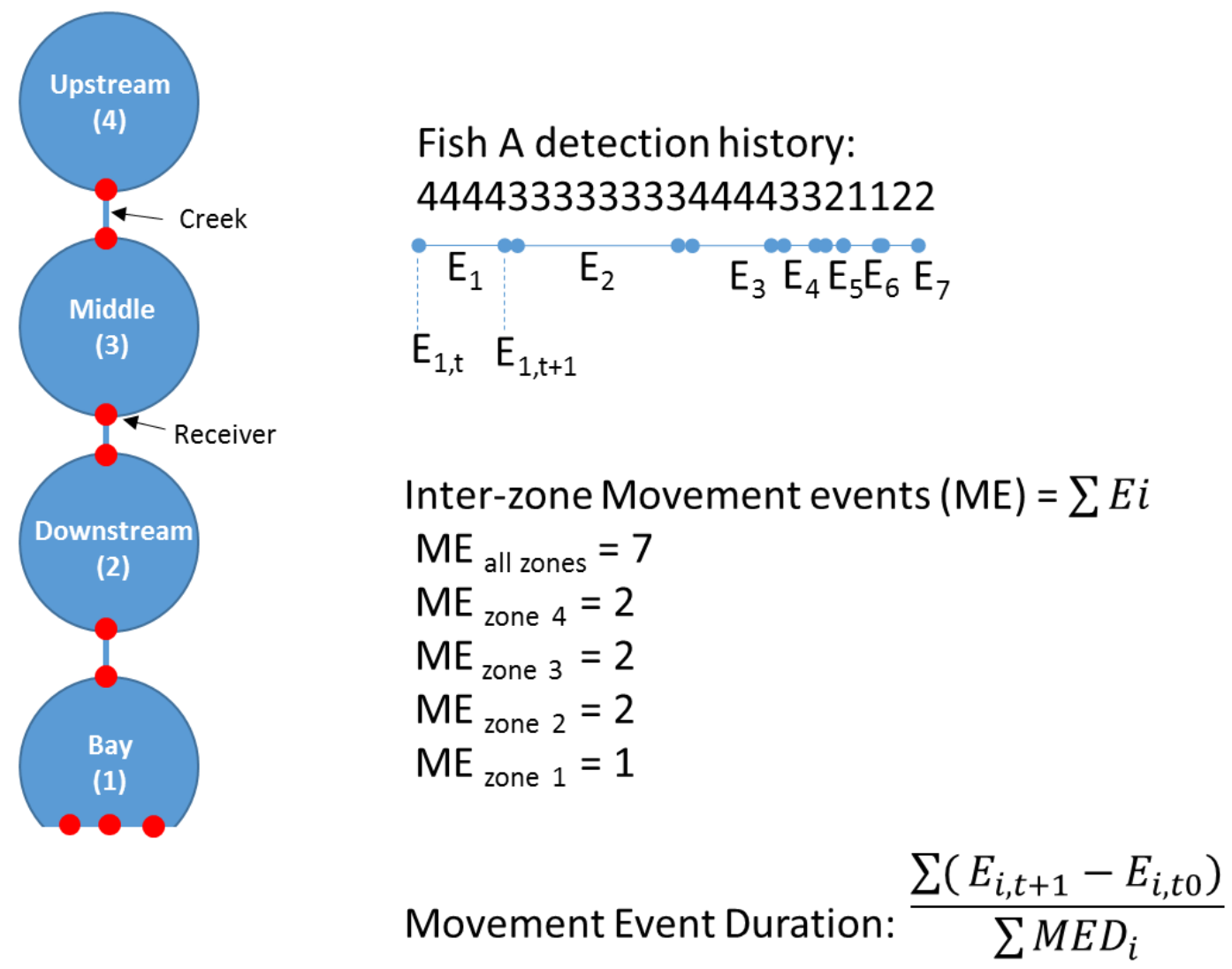
Figure A.2) Details of the detection histories of the 25 Snook tracked in the study by tag number. Lines connect the first and last detection for each Snook over the study duration (June 2016-June 2017), and are color coded by system. Detection histories ranged from 13 to 365 days, with an average of 216 days of detection. On average, we recorded 14,645 detections per Snook, and each Snook was detected by an average of 10 receivers.

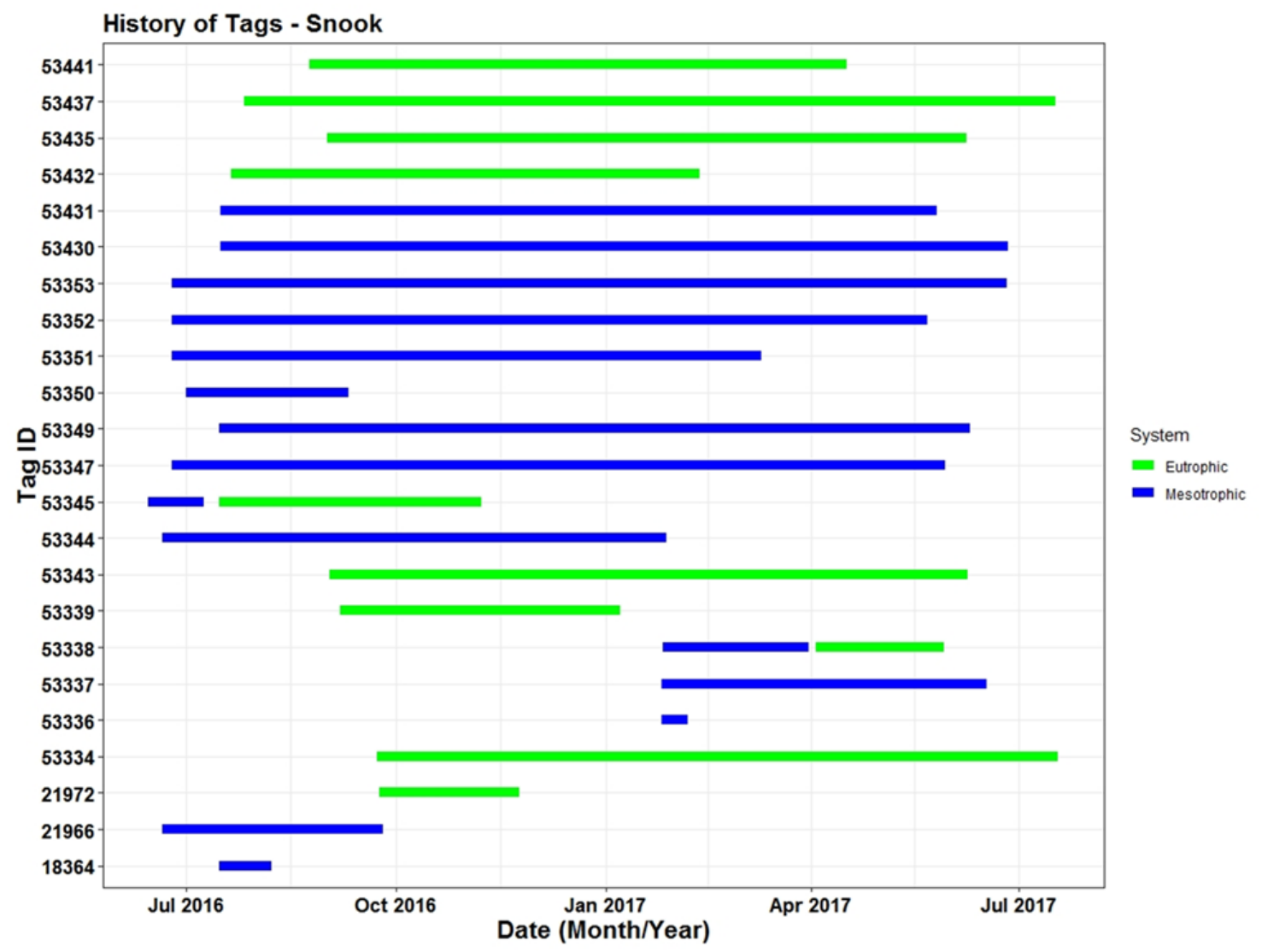

